\title{
An assessment of selected sub-systems of the Egyptian Norplant@ program
}

\author{
Fatma El-Zanaty \\ Laila Nawar \\ Ramadan Hamed
}

Follow this and additional works at: https://knowledgecommons.popcouncil.org/departments_sbsr-rh

Part of the Demography, Population, and Ecology Commons, Health Services Research Commons, and the International Public Health Commons How does access to this work benefit you? Let us know!

\section{Recommended Citation}

El-Zanaty, Fatma, Laila Nawar, and Ramadan Hamed. 2001. "An assessment of selected sub-systems of the Egyptian Norplant ${ }^{\circledR}$ program," FRONTIERS Final Report. Washington, DC: Population Council. 


\title{
An Assessment of Selected Sub-Systems of the Egyptian NORPLANT ${ }^{\circledR}$ Program
}

\author{
Fatma El Zanaty, Ph.D., Laila Nawar, Ph.D. and \\ Ramadan Hamed, Ph.D.
}

July, 2001 


\section{EXECUTIVE SUMMARY}

\section{Background}

There have been two sets of pre-introductory clinical trials of NORPLANT ${ }^{\circledR}$ implants in Egypt. The Rockefeller Foundation and the Population Council supported the first trial in the early 1980s and the Egyptian Fertility Care Society (EFCS), with support from the United States Agency for International Development (USAID) and technical assistance from Family Health International (FHI), conducted the second clinical trial in 1988.

Physicians from five university hospitals in Egypt provided NORPLANT ${ }^{\circledR}$ implants to 1,536 women during the period 1988-94. An acceptability study (EFCS 1995) indicated that 93 percent of the NORPLANT ${ }^{\circledR}$ clients surveyed were satisfied with the method.

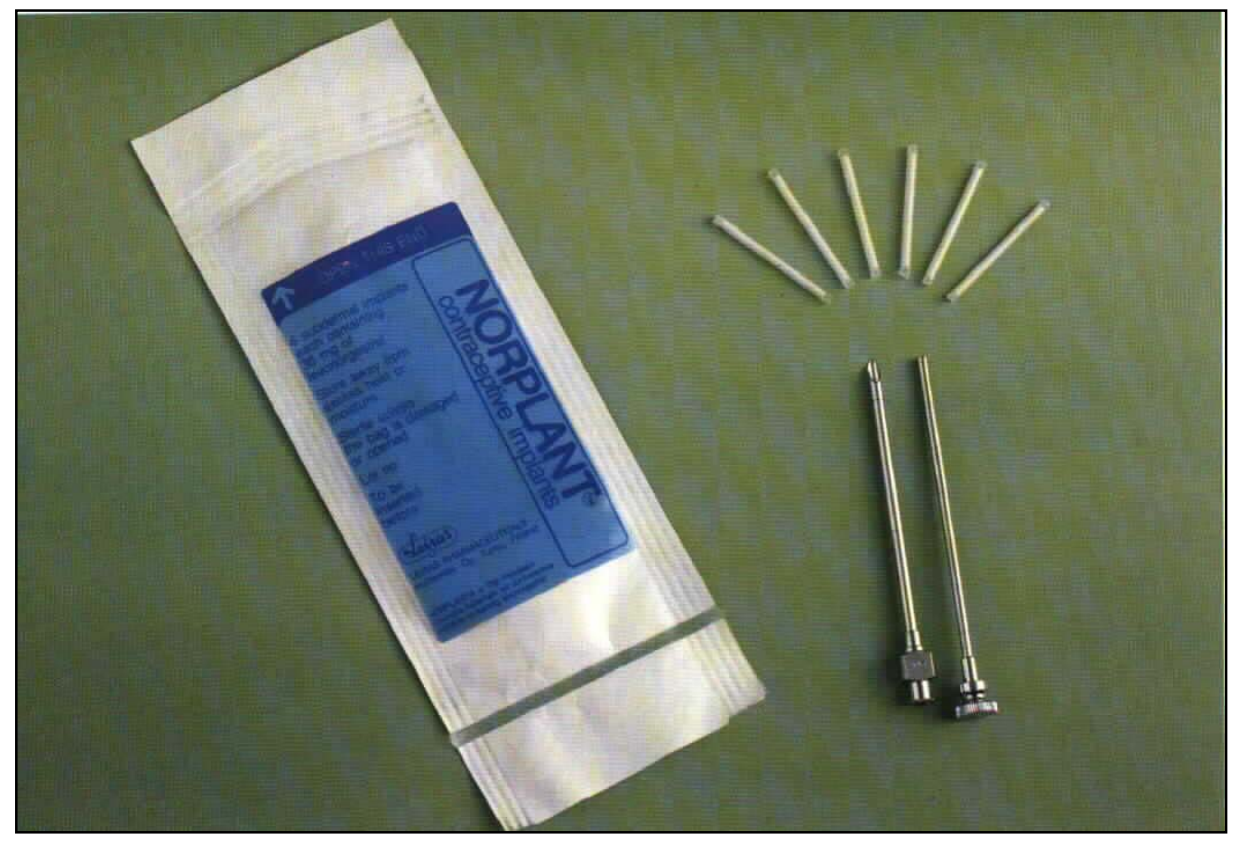

Based on the positive experience gained through these clinical trials, the Ministry of Health and Population's (MOHP) Central Administration for Family Planning decided to proceed with the development of the NORPLANT ${ }^{\circledR}$ Introductory Program and produced a strategy and regulations for NORPLANT ${ }^{\circledR}$ service provision.

The program began in November 1995 when NORPLANT ${ }^{\circledR}$ service provision was re-introduced in the five university hospitals that were included in the clinical trials. NORPLANT ${ }^{\circledR}$ service was then introduced to more university hospitals and teaching hospitals. In November 1996, it was decided to expand NORPLANT ${ }^{\circledR}$ services. The revised plan added the use of mobile teams, consisting of one physician and one nurse from university or teaching hospitals. These mobile teams visited MOHP health facilities according to predetermined schedules to provide one-day NORPLANT ${ }^{\circledR}$ services.

As of April 2000, NORPLANT ${ }^{\circledR}$ services have been provided in 11 university hospitals, 8 teaching hospitals and 93 MOHP health facilities. The mobile teams provided NORPLANT ${ }^{\circledR}$ insertions free of charge. However, insertions done through university and teaching hospitals as well as at the MOHP health facilities were provided for a fee (average LE 20). In mid-August 1999 the MOHP decided to provide NORPLANT ${ }^{\circledR}$ free of charge at all MOHP health facilities. This decision has 
substantially increased demand for NORPLANT ${ }^{\circledR}$ insertions at these sites. The MOHP and FRONTIERS began discussing the need for investigating these service delivery aspects in 1999. From those consultations this study emerged.

\section{Study Objectives}

The study has the following short-term objectives:

1. To assess the completeness and accuracy of the NORPLANT ${ }^{\circledR}$ central level management information system (MIS) and client record cards, specifically related to the ability of the NORPLANT ${ }^{\circledR}$ program to ensure the timely removal of expired NORPLANT ${ }^{\circledR}$ implants.

2. To identify factors influencing provider attitudes and motivation to provide NORPLANT ${ }^{\circledR}$ services.

3. To develop an understanding of NORPLANT ${ }^{\circledR}$ users' perspectives of the method, including their satisfaction with the services they have received and their knowledge about the need for timely removal.

\section{Study Methods}

The study employed an observational cross-sectional analysis of settings where NORPLANT ${ }^{\circledR}$ services are currently provided. It employed 4 types of data collection instruments and 2 types of research methods. An abbreviated audit of the client record system at selected facilities and an audit of the central level MOHP MIS of NORPLANT ${ }^{\circledR}$ users were conducted. In addition, NORPLANT ${ }^{\circledR}$ providers and users were interviewed.

The study compared information on clients obtained from the clinics' client records (in clinic registries and logbooks) to the actual client records available at the MOHP MIS central level to assess the reliability and completeness of the recording system and to check if information on the NORPLANT $^{\circledR}$ clients recorded in the health facility logbook was also included in the central level MIS.

A Standardized questionnaire was produced for use with all consenting physicians and nurses who provided NORPLANT ${ }^{\circledR}$ services at the study clinics, and who were available during the data collection period.

In addition, two categories of NORPLANT ${ }^{\circledR}$ users were requested to give consent for interviews:

1. Women who came to the study sites during the data collection period to have NORPLANT ${ }^{\circledR}$ inserted or to receive follow-up services within one month of insertion. These women were requested to consent to exit interviews. This group of women are referred to as "new users". 
2. Women who began NORPLANT ${ }^{\circledR}$ use between 1-4 years ago. These women were identified by their medical records and were contacted at their homes by the health care providers to ascertain if they would agree to an interview at the clinic or their home. This group of women are referred to as "continuing users".

The study was conducted in approximately one-third (36 sites in total) of the three types of health facilities providing services: MOHP, university and teaching hospitals, that were purposively chosen by a panel of experts.

The study instruments were pre-tested in five clinics that were not included in the study sites. Data collectors and supervisors participated in an intensive one-week training workshop that started on September 30, 2000. Data collection activities began in the second week of October 2000 and lasted for five weeks.

\section{Findings}

For all study sites, the study collected data on the mean monthly NORPLANT ${ }^{\circledR}$ caseload per clinic during the period August 1999 - September 2000 for both insertions and removals. The figures indicate that in general, for all the period shown, the monthly mean number of NORPLANT ${ }^{\circledR}$ insertions per clinic is 11.3 and the median is 9.5 with a range of mean insertions of $1.8-40.1$. Also, the monthly mean number of removals is 1.2 and the median is 0.1 , with a range of removals of $0-9.6$.

The majority of the physicians providing NORPLANT ${ }^{\circledR}$ services are male (62 percent) and more than one-half of them are 40 years old or more (mean age is about 41 years). More than 90 percent of the physicians have attained post-graduate degrees. Approximately 94 percent of the physicians who provide NORPLANT ${ }^{\circledR}$ services have attended training courses on the insertion and removal of NORPLANT $^{\circledR}$. Overall about one-half of the physicians who provide NORPLANT ${ }^{\circledR}$ reported a felt need for additional training in NORPLANT ${ }^{\circledR}$ removal.

About two-thirds of the nurses are less than 40 years old, with a mean age of 34 years. Overall, nurses reported working in NORPLANT ${ }^{\circledR}$ service provision for an average of almost two and onehalf years. However university hospital nurses had more experience in NORPLANT ${ }^{\circledR}$ service provision (mean number of years is 8.3). Almost all of the nurses have received training in family planning and the large majority (79 percent) have received training in NORPLANT ${ }^{\circledR}$ service provision. 
The study compared information on clients obtained from the clinics' client records (in clinic registries and log books) to the actual client records available at the MOHP MIS central level to assess the reliability and completeness of the recording system. Records that existed in both clinic registers and MIS represented about two-thirds (64\%) of the cases. One-third of clients' records were available in clinics' registers but not in the MIS.

A review of accuracy of the information was conducted for client records that existed in both the clinic and the central MIS (that produced a score of 1 for perfect fit and zero for no fit). Findings indicated that accuracy for the insertion date is high (0.95), moderate for the insertion complications (0.67), low for removal date (0.4) and last family planning used (0.48), and very low for the woman's address $(0.25)$.

With regard to accuracy of the clients' addresses, the study indicates that only about 56 percent of the continuing users selected at random for the home interview were actually reached using the locator information on the client records. An additional 37 percent of NORPLANT ${ }^{\circledR}$ clients could not be located because their addresses were incomplete. Furthermore, in the majority of clients' records information on the relative's address was not collected.

During the home interview, the study also assessed if each continuing user was given a follow-up card as well as the accuracy of the information recorded in that card. Nearly half (45\%) of continuing NORPLANT ${ }^{\circledR}$ users received a card and were still keeping it. Two-fifths (40\%) received the follow-up card but it was later lost. In 15 percent of cases, women said that they did not receive a card. Cases in which the card was available also indicated some discrepancies in accuracy of information recorded on the card, but overall the information on the client card corresponded with the clinic records particularly on the year of insertion.

Physicians were asked about their views about NORPLANT ${ }^{\circledR}$ advantages and disadvantages. The advantages most frequently mentioned were that NORPLANT ${ }^{\circledR}$ is a long-acting method (reported by 71 percent) and that it is a safe and effective method (61 percent). About one-half of physicians mentioned that women do not need to remember doing anything to avoid pregnancy, like taking a pill daily. The most frequently reported disadvantage of NORPLANT ${ }^{\circledR}$ is that it causes menstrual cycle disturbance (reported by $62 \%$ of physicians). The next most frequently mentioned disadvantage is that it sometimes causes severe bleeding (42\%), followed by difficulty of removal (36\%). In general, the study findings did not suggest the presence of negative attitudes by service providers towards NORPLANT ${ }^{\circledR}$ as a family planning method. 
The study findings indicated a lack of consensus among physicians about NORPLANT ${ }^{\circledR}$ contraindications and suggest the need for more training of physicians on this issue. Also, physicians faced difficulties in NORPLANT ${ }^{\circledR}$ removal. About two-fifths (43\%) of physicians who had ever removed NORPLANT ${ }^{\circledR}$ reported that the most frequent problems met were that the site of implanted capsules was not clear (36\%) and the difficulty of removing all rods in one session (32\%).

Although the majority of physicians reported that there is a system in place to follow-up clients who fail to make follow-up visits, about four-fifths of physicians (80\%) reported that there is no mechanism in place to do home visits for those women. The implication is that women who may forget the removal date will not be contacted by clinic staff to be advised for removal.

The study findings indicated that about $10 \%$ of the new users had not previously used another method before NORPLANT ${ }^{\circledR}$. The IUD and injectables were used each by about one-third of the new NORPLANT ${ }^{\circledR}$ users and the pill was used by about one-fourth of the women before they switched to NORPLANT ${ }^{\circledR}$.

This study also collected information on counseling and information given to clients by service providers before and after NORPLANT ${ }^{\circledR}$ insertion. Almost all of the women (96\%) reported being told about the use duration of NORPLANT ${ }^{\circledR}$, (i.e., five years). About two-thirds were told about NORPLANT $^{\circledR}$ advantages and one-half were told about NORPLANT ${ }^{\circledR}$ insertion procedures. However, counseling on potential side-effects was provided to only $39 \%$ of the women.

The majority reported being told about the need for follow-up visits (92\%). However, only $85 \%$ reported that they received a card including the schedule for follow-up visits. Only about one-fourth of women were told about the due date for removal before they left the clinic. In addition, about $69 \%$ of women were advised what to do in case they experienced side-effects.

The study examined the satisfaction with the NORPLANT ${ }^{\circledR}$ method and related aspects of service provision received among new users. Almost all new clients $(98 \%)$ reported that the insertion procedure went well and no problems were faced. About (74\%) reported that they didn't feel pain or fear during the insertion procedure. Most (89\%) of the new users who received a free method reported that they would still request NORPLANT ${ }^{\circledR}$ insertion if they were asked to pay for it. About three-fourths $(76 \%)$ of the new users who paid for the method reported that the payment made was reasonable (mean payment for the method was LE 16.9). 
The study also collected data on the experiences of continuing users $(n=624)$ of NORPLANT ${ }^{\circledR}$ (i.e., women who had NORPLANT ${ }^{\circledR}$ inserted 1-4 years ago). The two most commonly cited advantages to NORPLANT ${ }^{\circledR}$ use among this group are its long duration (36\%) and fewer side effects (24\%). Some of the continuing users mentioned that they had less side-effects with NORPLANT ${ }^{\circledR}$ or sideeffects that were more tolerable compared with other family planning methods that they tried before NORPLANT ${ }^{\circledR}$.

With regard to the principal disadvantage, about two-fifths (42\%) of the continuing users do not perceive any disadvantage for NORPLANT ${ }^{\circledR}$. The most frequently reported disadvantage was that NORPLANT $^{\circledR}$ causes menstrual cycle disturbance (cited by $26 \%$ ). Other reported disadvantages included headache, weight gain and pain (reported each by about $6 \%$ ).

Home interviews indicated that about 17 percent of woman $(n=103)$ had NORPLANT ${ }^{\circledR}$ removed before 5 years of use. Experiencing bleeding was the main cause of dissatisfaction with the method that led to early removal (reported by about one-half of women who stopped using NORPLANT ${ }^{\circledR}$ ). An additional one-fourth mentioned that they had NORPLANT ${ }^{\circledR}$ removed because of its other sideeffects. The decision to remove NORPLANT ${ }^{\circledR}$ was primarily made by the woman herself $(62 \%)$, while $29 \%$ of the women stated that the physician recommended removal.

Both NORPLANT ${ }^{\circledR}$ continuers and discontinuers were asked about the duration of NORPLANT ${ }^{\circledR}$ use since insertion. The study findings indicated that about one-half of woman who discontinued NORPLANT $^{\circledR}$ use had the implants removed before the second year of use. Overall, the average duration of NORPLANT ${ }^{\circledR}$ use among continuers and discontinuers was 1.8 and 1.4 years, respectively.

Both continuing users and discontinuers were asked about side-effects experienced during NORPLANT $^{\circledR}$ use. As expected, substantially higher proportions of NORPLANT ${ }^{\circledR}$ discontinuers $^{-1}$ reported experiencing NORPLANT ${ }^{\circledR}$ side-effects compared to the continuers group. Among the discontinuers group the most frequently reported side-effects experienced were severe bleeding (47\%), weight changes (39\%), menstrual cycle disturbance (35\%) and suffering continuous headache $(28 \%)$. For the continuers group, the most frequently reported side-effects for NORPLANT $^{\circledR}$ were menstrual cycle disturbance (30\%), amenorrhoea $(18 \%)$ and weight changes $(17 \%)$.

Women who had NORPLANT ${ }^{\circledR}$ removed $(n=103)$ did report some difficulties with the removal experience. About one-half of women said that the removal procedure was difficult (e.g. felt pain, 
too long removal time). About one tenth complained that they had to make at least two visits to the clinic to have NORPLANT ${ }^{\circledR}$ removed.

Seventy-one percent of women who had NORPLANT ${ }^{\circledR}$ removed switched to another family planning method after removal. Among this group, about 38\% switched to the IUD, about 33\% switched to the pill, and about $26 \%$ switched to injectables.

Among all of the sample women who began using NORPLANT ${ }^{\circledR}$ between 1-4 years ago, the vast majority reported general satisfaction with the method, and the services. About $80 \%$ reported having no felt pain or fear during the insertion procedure. Almost all women who reported that the rods were recognized by others in their arms $(n=139)$ indicated that they were not annoyed because of that. About 90 percent of women who were still using NORPLANT ${ }^{\circledR}$ intend to continue NORPLANT ${ }^{\circledR}$ use to the end of the five-year duration. Almost two-thirds (61\%) of all women stated that they would recommend NORPLANT ${ }^{\circledR}$ to others. However, women who discontinued NORPLANT $^{\circledR}$ use $(n=103)$ were less satisfied with the method. Only 42 percent of this group reported that they were comfortable with NORPLANT ${ }^{\circledR}$ use and 28 percent said that they will recommend NORPLANT ${ }^{\circledR}$ to others.

The study raised a number of recommendations. They addressed issues related to quality of care, program sustainability and the ability of MOHP MIS to track and locate women eligible for removal, including:

1. Provide further training to service providers involved in NORPLANT ${ }^{\circledR}$ service provision. Assessment of the specific training needs for quality NORPLANT ${ }^{\circledR}$ service provision is needed.

2. Promote accessibility to removal services and quality of these services.

3. Develop adequate client follow-up systems to contact clients eligible for removal

4. Develop an integrated quality oriented monitoring and evaluation system for NORPLANT ${ }^{\circledR}$ service delivery sites.

5. Reconsider the decision to provide NORPLANT ${ }^{\circledR}$ free of charge, in view of the findings on women's readiness to pay for NORPLANT ${ }^{\circledR}$ among the majority of women who received a free method to promote NORPLANT ${ }^{\circledR}$ program sustainability.

6. Develop appropriate mechanisms to promote central MIS capacity to locate and track women to ensure that women have NORPLANT ${ }^{\circledR}$ removed or replaced when they become no longer effective. 


\section{CONTENTS}

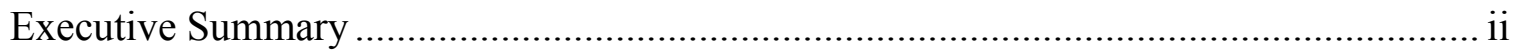

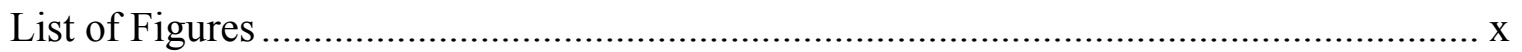

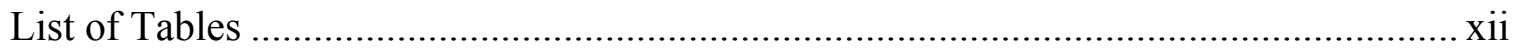

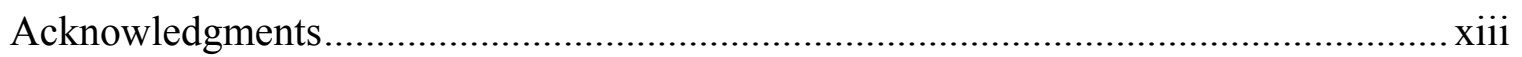

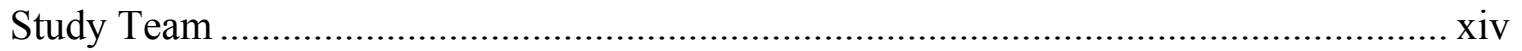

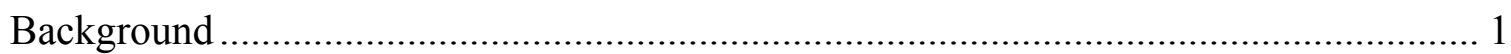

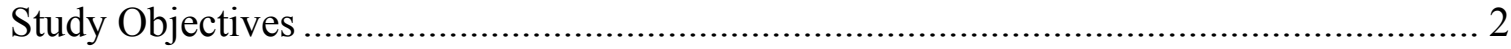

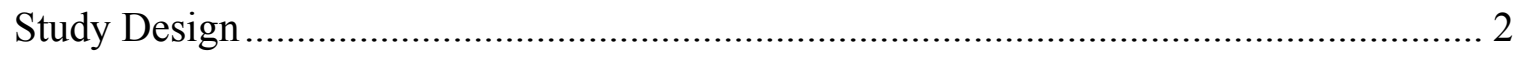

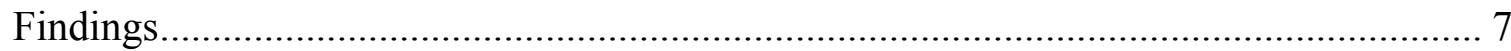

Overview of Findings and Program Implications ..................................................... 29

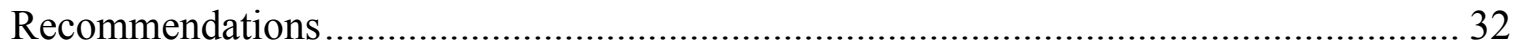

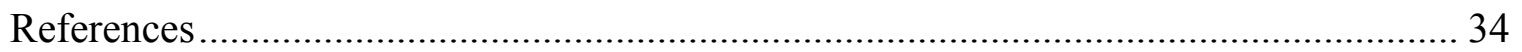




\section{LIST OF FIGURES}

Figure 1: Average monthly number of NORPLANT ${ }^{\circledR}$ insertions and removals 8

Figure 2: Agreement on key indicators between client record information at MIS central level and clinic level

Figure 3 : Decision making roles on FP methods as reported by NORPLANT ${ }^{\circledR}$ physicians

Figure 4 : What are the advantages of NORPLANT ${ }^{\circledR}$ ?

Figure 5 : What are the disadvantages of NORPLANT ${ }^{\circledR}$ ? 14

Figure 6 : What is the information you provide to women who come to insert NORPLANT ${ }^{\circledR}$ ? 15

Figure 7 : What are the contraindications of NORPLANT ${ }^{\circledR}$ use? . 15

Figure 8 : Difficulties in Removal of NORPLANT ${ }^{\circledR}$ Implants 16

Figure 9: What are the infection control procedures that should be followed during NORPLANT ${ }^{\circledR}$ insertion/removal? 16

Figure 10 : Follow-up care provided to women who inserted NORPLANT ${ }^{\circledR}$ 17

Figure 11 : Physicians' reports on what they do in case of facing NORPLANT ${ }^{\circledR}$ shortage......... 17

Figure 12 : Mechanisms for the promotion of NORPLANT ${ }^{\circledR}$ services 18

Figure 13: What are the five most important problems in NORPLANT ${ }^{\circledR}$ service provision? ..... 19

Figure 14 : Previous FP method used among new NORPLANT ${ }^{\circledR}$ users 20

Figure 15 : Factors affecting the decision to accept NORPLANT ${ }^{\circledR}$ among new users 21

Figure 16 : Information given to new clients by service providers 21

Figure 17 : Follow-up information given to new acceptors after NORPLANT ${ }^{\circledR}$ insertion 22

Figure 18 : Satisfaction with NORPLANT ${ }^{\circledR}$ methods and services among new clients. 23

Figure 19 : Continuing users reports on principal advantage and disadvantage of NORPLANT ${ }^{\circledR} 23$

Figure 20 : Principal reason for discontinuing use of NORPLANT ${ }^{\circledR}$ before 5 years 24

Figure 21 : Duration of NORPLANT ${ }^{\circledR}$ use (continuers) 25

Figure 22 : Duration of NORPLANT ${ }^{\circledR}$ use (Discontinuers). 26

Figure 23 : Side effects experienced during NORPLANT ${ }^{\circledR}$ use 26 
Figure 24 : Switching to another method among NORPLANT ${ }^{\circledR}$ discontinuers 28

Figure 25 : Selected indicators on client satisfaction with NORPLANT ${ }^{\circledR}$ method/service.......... 28 


\section{LIST OF TABLES}

Table 1: Sample sites by location and type of facility .............................................................. 4

Table 2: Sampling results for the Home Interviews with continuing users of NORPLANT ${ }^{\circledR}$..... 5

Table 3: Sampling results (completed forms) by type of health facility................................. 7

Table 4: Study sites by type and selected characteristics $(\mathrm{n}=36$ clinics $)$................................ 7

Table 5: Selected socio-demographic characteristics of physicians who provide

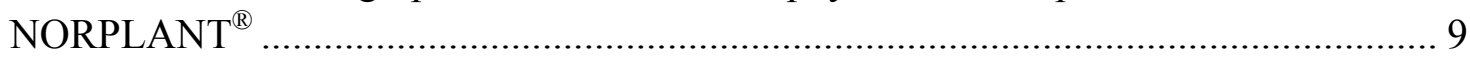

Table 6: Selected socio-demographic characteristics of nurses ........................................... 10

Table 7: Selected socio-demographic and economic characteristics of new

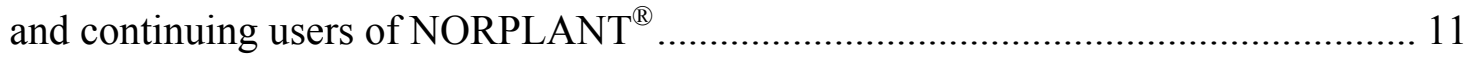

Table 8: Matching client records at MIS central level and clinic level ................................... 12

Table 9: Client follow-up cards: receipt by NORPLANT ${ }^{\circledR}$ users and agreement of

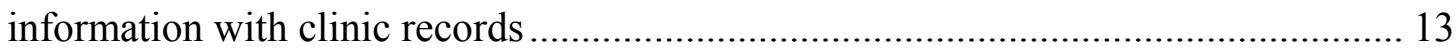

Table 10: Source of information on NORPLANT ${ }^{\circledR}$ among new users ................................... 20

Table 11: Decision makers and place of removal as reported by discontinued users $(n=103) \ldots 25$

Table 12: Experience with NORPLANT ${ }^{\circledR}$ removal as reported by discontinued users............. 27

Table 13: Tolerance of side-effects and medical assistance received.................................... 27 


\section{ACKNOWLEDGMENTS}

El Zanaty \& Associates team would like to acknowledge the support and dedication of a large number of institutions and individuals. The support of Dr. Yehia El-Hadidi, the General Director of Population and Family Planning Sector/ MOHP, has been instrumental in the successful implementation of this study. Many thanks are also extended to Dr. Morsy Mansour, the National NORPLANT $^{\circledR}$ Program Coordinator, for his supportive role in facilitating the data collection activities.

We are deeply grateful to the technical assistance received from the Population Council's Frontiers in Reproductive Health Program staff, which made the conduct of this study possible. Without their technical support this study would have not been completed.

We would also like to acknowledge the United States Agency for International Development (USAID) for supporting the implementation of this study and for the valuable comments received.

Our deep appreciation is also due to all physicians and nurses working in NORPLANT ${ }^{\circledR}$ service provision for their cooperation during data collection phase.

Also, our thanks and appreciations are extended to each member of El-Zanaty \& Associates' team, including professional, administrative and field staff. Their hard work and dedication made possible the conduct of this study.

Finally, we would like to express our appreciation to all clients who were interviewed in this study. Without their participation, this study would have been impossible to undertake. 


\section{STUDY TEAM}

El Zanaty \& Associates Team

$\begin{array}{ll}\text { Fatma Hassan El- Zanaty } & \text { Principal Investigator } \\ \text { Ramadan Hamed } & \text { Study Coordinator }\end{array}$

\section{Senior staff}

Faten Abd El-Fattah

Madiha El-Banhawy

Zakaria Abd El-Samea

Data processing and statistics

Rashad Hamed

Mohamed Abou El-Ella

$\underline{\text { Research Assistant }}$

Mohamed El-Ghazaly

\section{Administrative Support}

Wegdan Yehia Hussian

Atef Mohamed Sayed

\section{Data Collection Team}

Moneir Ibrahim

Gamal Hashem

Mohamed Ahmed

Alaa Badr

Hany Mohamed

Hany El-Beltagy

Mahmoud Shahata

Wael Abd El-Karim

Mahamed Mahrous

Amr Shokry

Rashed Essam El-Din

Mohamed Salim

Mohamed El-Dabaa

Osman Awad

Hoda Mahmoud

Doaa Mohamed Hassan

Hanaa Solaiman

Gehan Refaat

Mona Moustafa

Hanaa Kotb

Ghada Moustafa

Noha Fakhry

Doaa Ibrahim

Farida Said

Hanaa Ibrahim

Naglaa Hassan

Nafesa Mohamed

Nevien Sabry

Eyman Ramadan
Field work Coordinator

Supervisor

Supervisor

Supervisor

Supervisor

Supervisor

Supervisor

Supervisor

Supervisor

Supervisor

Supervisor

Supervisor

Supervisor

Supervisor

Interviewer

Interviewer

Interviewer

Interviewer

Interviewer

Interviewer

Interviewer

Interviewer

Interviewer

Interviewer

Interviewer

Interviewer

Interviewer

Interviewer

Interviewer 
Sahr Abd El-Rahman

Hanaa Abd El-Karim

Afaf Awad

Eyman Youssef

Marwa Mohamed

Rehab Fawzy

Mervat Zaghloul

Randa Abd El-Kader

Amal Refaat

Rabab Abd El-Fattah

Sherien Ayman

Sanaa Abd El-Atty

Gehan Ragab

Eyman Karam

Reham Hussain

Randa Moustafa

Reda Farouk

Asmaa Zakaria

Manal Mamdoh

Noha Mohamed

Sanaa Ahmed

Naglaa Fathy
Interviewer

Interviewer

Interviewer

Interviewer

Interviewer

Interviewer

Interviewer

Interviewer

Interviewer

Interviewer

Interviewer

Interviewer

Interviewer

Interviewer

Interviewer

Interviewer

Interviewer

Interviewer

Interviewer

Interviewer

Interviewer

Interviewer

\section{Population Council's FRONTIERS Team}

Laila Nawar

Maha El Rabbat

Dale Huntington

Sahar Hegazi

Ibrahim Kharboush

\section{Admin Support}

Gihan Hosny
WANA Regional Advisor and Co-PI

Program Officer

Regional Director, ANE

Regional Communication Officer

Fellow

FRONTIERS Executive Secretary 


\section{BACKGROUND}

There have been two sets of pre-introductory clinical trials of NORPLANT ${ }^{\circledR}$ implants in Egypt. The Rockefeller Foundation and the Population Council supported the first trial in the early 1980s and the Egyptian Fertility Care Society (EFCS), with support from the United States Agency for International Development (USAID) and technical assistance from Family Health International (FHI), conducted the second clinical trial in 1988. Physicians from five university hospitals in Egypt provided NORPLANT ${ }^{\circledR}$ implants to 1,536 women during the period 1988-94. An acceptability study (EFCS 1995) indicated that 93 percent of the NORPLANT ${ }^{\circledR}$ clients surveyed were satisfied with the method. Based on the positive experience gained through these clinical trials, the Ministry of Health and Population's (MOHP) Central Administration for Family Planning decided to proceed with the development of the NORPLANT ${ }^{\circledR}$ Introductory Program and produced a strategy and regulations for NORPLANT ${ }^{\circledR}$ service provision. This provided guidelines for expanding the use of NORPLANT ${ }^{\circledR}$ beyond the university hospital environment of the clinical trials.

In November 1994 a task force was created that designed

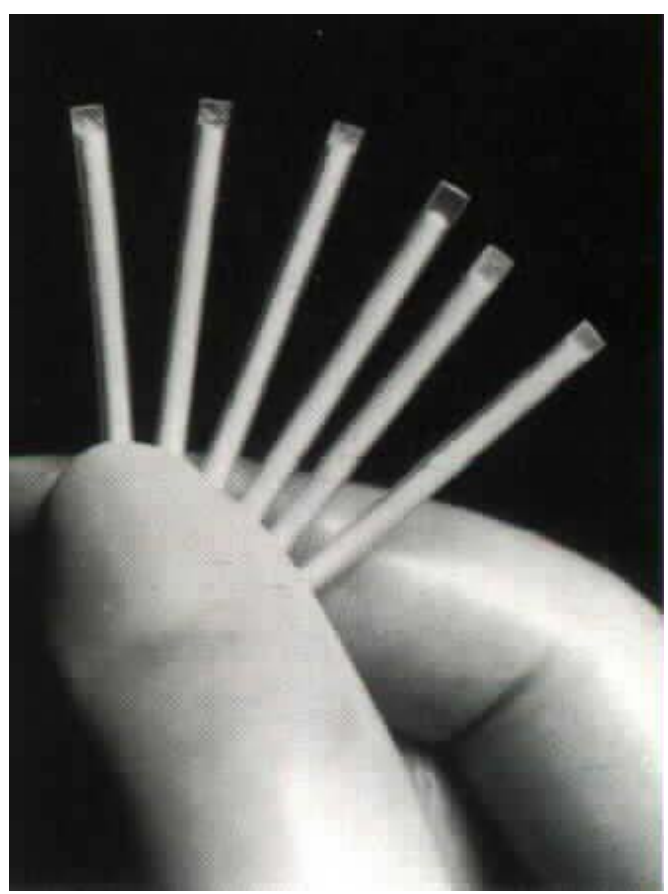
the NORPLANT ${ }^{\circledR}$ Introduction Program. The original plan for the Program included two elements. The first element was a broad geographic (horizontal) introduction of NORPLANT ${ }^{\circledR}$ that would offer leading OB/GYN specialists throughout Egypt experience in providing this new contraceptive. The second element was the vertical introduction of NORPLANT ${ }^{\circledR}$ in two governorates designed to include more types of health facilities. The Program began in November 1995 when NORPLANT ${ }^{\circledR}$ service provision was re-introduced in the five university hospitals that were included in the clinical trials. NORPLANT ${ }^{\circledR}$ service was then introduced to more university hospitals and teaching hospitals. In November 1996 the task force decided to expand NORPLANT ${ }^{\circledR}$ services to selected urban MOHP sites and to modify the original plan for expanding NORPLANT ${ }^{\circledR}$ services. The revised plan added the use of mobile teams, consisting of one physician and one nurse from university or teaching hospitals. These mobile teams visited MOHP health facilities according to predetermined schedules to provide one-day NORPLANT ${ }^{\circledR}$ services.

As of April 2000, NORPLANT ${ }^{\circledR}$ services have been provided in 11 university hospitals, 8 teaching hospitals and 93 MOHP health facilities. The mobile teams provided NORPLANT ${ }^{\circledR}$ insertions free 
of charge. However, insertions done through university and teaching hospitals as well as at the MOHP health facilities were provided for a fee (average LE 20). In mid-August 1999 the MOHP decided to provide NORPLANT ${ }^{\circledR}$ free of charge at all MOHP health facilities. This decision has substantially increased demand for NORPLANT ${ }^{\circledR}$ insertions at these sites.

There are several critical elements to providing high quality NORPLANT ${ }^{\circledR}$ services, including the following:

- the completeness of client records at the service delivery sites

- the maintenance and linkage of local and central level registries of users

- the capacity of local facilities to track and locate women who fail to return for removal, and providers' technical knowledge and attitudes about providing NORPLANT ${ }^{\circledR}$

The MOHP and FRONTIERS began discussing the need for investigating these service delivery aspects in 1999. From those consultations this study emerged.

\section{STUDY OBJECTIVES}

\section{Long-term Objective}

This study will help ensure that providers offer NORPLANT ${ }^{\circledR}$ in a balanced and culturally sensitive way with proper attention to safety and quality issues, and the needs of users.

\section{Immediate Objectives}

The study has the following short-term objectives:

1. To assess the completeness and accuracy of the NORPLANT ${ }^{\circledR}$ central level management information system (MIS) and client record cards, specifically related to the ability of the NORPLANT ${ }^{\circledR}$ program to ensure the timely removal of expired NORPLANT ${ }^{\circledR}$ implants.

2. To identify factors influencing provider attitudes and motivation to provide NORPLANT ${ }^{\circledR}$ services.

3. To develop an understanding of NORPLANT ${ }^{\circledR}$ users' perspectives of the method, including their satisfaction with the services they have received and their knowledge about the need for timely removal.

\section{STUDY DESIGN}

The study employed an observational cross-sectional analysis of settings where NORPLANT ${ }^{\circledR}$ services are currently provided. NORPLANT ${ }^{\circledR}$ providers (physicians and nurses) were interviewed, at the facility where they work. In addition two categories of NORPLANT ${ }^{\circledR}$ users were requested 
to give consent for interviews:

1. Women who came to the study sites during the data collection period to have NORPLANT ${ }^{\circledR}$ inserted or to receive follow-up services within one month of insertion. This group was requested to consent to exit interviews.

2. Women who began NORPLANT ${ }^{\circledR}$ use between 1-4 years ago. These women were identified by their medical records and were contacted at their homes by the health care providers to ascertain if they would agree to an interview at the clinic or their home. An abbreviated audit of the client record system at selected facilities and an audit of the central level MOHP MIS of NORPLANT ${ }^{\circledR}$ users were conducted.

\section{Study Instruments and Research Methods}

The study employed 4 types of data collection instruments and 2 types of research methods.

\section{Record system audit}

The study compared information on clients obtained from the clinics' client records (in clinic registers and logbooks) to the actual client records available at the MOHP MIS central level to assess the completeness of the recording system, and to check if information on NORPLANT ${ }^{\circledR}$ clients recorded in the health facility logbook was also included in the central level MIS. A review of the accuracy of the information was also conducted for client records that existed in both the clinic and the central MIS.

\section{Provider interviews}

A standardized questionnaire was produced for use with all consenting physicians and nurses who provided NORPLANT ${ }^{\circledR}$ services at the study sites, and who were available during the data collection period.

\section{Exit interviews}

Standardized interviews were conducted with consenting women who had just received NORPLANT ${ }^{\circledR}$ insertion at the study sites. Interviews were also conducted with women who came to the clinic for a follow-up visit after one month of insertion and had just received services and counseling. This group of women will be referred to as "new users" in the study findings sections.

\section{Home interviews}

Follow-up interviews were conducted with randomly selected women who had NORPLANT ${ }^{\circledR}$ inserted between 1-4 years ago at facilities included in the study sample. This group of women will be referred to as "continuing users" in the study findings sections (keeping in mind that some of these women discontinued NORPLANT ${ }^{\circledR}$ use later). 


\section{Sampling Procedures}

NORPLANT $^{\circledR}$ services are provided in

11 university hospitals, 8 teaching

hospitals and 93 MOHP hospitals. The study was conducted in a purposively chosen sample of approximately onethird of these sites to ensure selection of the three types of health facilities providing NORPLANT ${ }^{\circledR}$ services:

MOHP, university and teaching hospitals. Table 1 shows the selected study sites in the 15 governorates covered. Twenty-nine clinics were selected from MOHP, three clinics from university hospitals and four clinics from teaching hospitals, yielding a total of 36 sites in the study.

\section{Record system audit}

Twenty client entries were selected randomly from the MIS for each of the study's 36 clinics. These entries were transcribed on the blank client record sheets ${ }^{1}$ that MOHP clinics use to
Table 1: Sample Sites by Location and Type of Facility

\begin{tabular}{|l|l|l|}
\hline Governorate & Clinic & Type \\
\hline Cairo & El-Demerdash & University \\
& El- Mataria & Teaching \\
& Mansheit El- Bakry & MOHP \\
& Dar El- Salam & MOHP \\
& El- Monera(General) & MOHP \\
& El- Zawia El- Hamraa. & MOHP \\
\hline Alexandria & Atfal El- Raml & MOHP \\
& Dar Ismail & MOHP \\
& El- Amria & MOHP \\
\hline Port Said & El- Nasr & MOHP \\
& El- Manakh & MOHP \\
\hline Dakahlia & El- Mansoura & University \\
& Aga & MOHP \\
& Dekarnes & MOHP \\
\hline Qaloubia & Banha & Teaching \\
& Kalub & MOHP \\
& Dar El- Welada & MOHP \\
\hline Menofia & Shebein El- Kom & Teaching \\
\hline Kafr El Sheikh & Kafr El-Sheikh & MOHP \\
& Kelein & MOHP \\
\hline Behira & Kafr El- Dawar & MOHP \\
\hline Ismailia & El- Kantara & MOHP \\
\hline Beni Suef & Beni Suef(General) & MOHP \\
\hline Fayoum & Naser & MOHP \\
\hline Menya & Ebsheway & MOHP \\
& Tameia & MOHP \\
\hline Assuit & Sozan Mobark Center & MOHP \\
& El- Menya (General) & MOHP \\
\hline Qena & Assuit & University \\
& Assuit (General) & MOHP \\
& El- Badary & MOHP \\
\hline Souhag & Abou Manaa Bahari & MOHP \\
& Nekada & Mouhag \\
\hline
\end{tabular}

record information for women who have had NORPLANT ${ }^{\circledR}$ inserted. Data collectors were instructed to locate data from client record sheets from the clinic registers/logbooks. For some clinics the total available MIS records were less than 20 cases. In these small caseload clinics all of the available records were used. The information collected from the clinics' registers/logbook was then compared with the information retrieved from the central MIS. Discrepancies were detected (both completely missing cases and cases with non-matching information). A form was developed that used an ordinal ranking of the fit between these two independent data sources and also of the degree of completeness of the information. The ranking classified each data item as either 0 (no fit) or 1 (perfect fit).

\footnotetext{
${ }^{1}$ The client record sheet includes data on client's name, some socio-demographic data (e.g., age, parity, education), date of insertion, client's address and husband name, name and address of one of the client's relatives (not residing at the same household), name of the physician who inserted NORPLANT ${ }^{\circledR}$, expected date of removal, actual removal date and reasons for removal. This sheet included 19 data items.
} 


\section{Client follow-up card audit}

During home interviews, each woman was asked if she has received a follow-up card from the clinic. The information recorded on the card (if available) was copied on a form that was designed for this purpose. The corresponding information from the clinic's registers was also copied on the same form. Information of these two sources was then matched in the office.

\section{Monthly caseload and staffing information}

A clinic form was designed to collect information from each of the study sites on the number and types of service providers, the number of service providers who received training on NORPLANT ${ }^{\circledR}$ insertion/removal, the year that NORPLANT ${ }^{\circledR}$ services were first provided, and the availability of client follow-up services and other information related to NORPLANT ${ }^{\circledR}$ insertion and removal. This form also abstracted data on NORPLANT ${ }^{\circledR}$ monthly caseload (insertion/removal) from each clinic's logbook for the 14 month period of August 1999-September 2000.

\section{Home interviews of continuing users}

Women eligible for home interviews were defined as those women who had NORPLANT ${ }^{\circledR}$ inserted between 1 to 4 years ago. Clinic staff (usually nurses) in each of the study's 36 sites were instructed in systematic random selection procedures to identify 18 client names from the clinic register/ logbook for a total of 648. Special forms were developed for recording locator information, (the woman's name, her husband's name and her address). Due to inaccuracies in addresses and other difficulties in locating the woman (even if

Table 2: Sampling Results for the Home Interviews with Continuing Users of NORPLANT ${ }^{\circledR}$

\begin{tabular}{|l|r|r|}
\hline \multicolumn{1}{|c|}{ Outcome of interview } & Percent & \multicolumn{1}{c|}{ N } \\
\hline Completed & 55.5 & 624 \\
\hline Address not located & 37.2 & 419 \\
\hline $\begin{array}{l}\text { Address located but no woman with } \\
\text { same name }\end{array}$ & 2.7 & 30 \\
\hline Refused & 0.2 & 2 \\
\hline Other* & 4.4 & 50 \\
\hline Total & $\mathbf{1 0 0 . 0}$ & $\mathbf{1 , 1 2 5}$ \\
\hline
\end{tabular}

*women who received NORPLANT ${ }^{\circledR}$ service in other governorates through mobile teams and were registered in the clinics' logbooks the address was correct), additional women were randomly selected to reach the target number of home interviews. A total of 624 home interviews were completed out of 1,125 randomly selected clients (55 percent) (see Table 2). The majority of clients included in the sample of home interviews were women who had NORPLANT ${ }^{\circledR}$ inserted less than two years ago (because of the lack of information in clinic registers on women who had NORPLANT ${ }^{\circledR}$ inserted more than two years ago). However, due to incomplete logbooks, missing addresses, and the unavailability of logbooks in some clinics for more than two years, it was necessary to include in this sample some women who had NORPLANT ${ }^{\circledR}$ inserted less than 12 months ago to achieve the target sample. For this latter group ( $\mathrm{n}=174)$, the mean duration of insertion is 8.4 months and the median is 10 months. Clinic staff (usually the Raida or the nurse) approached the women selected for home interviews to obtain their informed consent. Consenting women were given the option of either visiting the health facility to meet with the female interviewer or conducting the interview at home, at their convenience. 


\section{Exit Interviews}

All eligible NORPLANT ${ }^{\circledR}$ users were contacted after they had received services and were asked to give consent for an interview. This process continued in each clinic until 20 clients were interviewed.

\section{Data Collection Procedures}

\section{Pre-test of the study instruments}

The study instruments were pre-tested in five clinics that were not included in the study sites. The pre-test training lasted for three days. Two teams were involved in the pre-test activities for one week. Each team consisted of five interviewers and two supervisors. Review sessions were held with the interviewers and supervisors to get their feedback. Necessary changes were made to the study instruments by El-Zanaty \& Associates and the Population Council staff.

\section{Training of data collectors}

Data collectors and supervisors participated in an intensive one-week training workshop that started on September 30,2000. Approximately 40 female interviewers and 15 male supervisors attended the training. The training included information on the NORPLANT ${ }^{\circledR}$ program in Egypt and intensive training on how to fill out the study instruments using appropriate visual aids. The principal investigator and research coordinator led training sessions over four days. The last two days of the training workshop included role plays and a quiz. Finally, 36 interviewers and 13 supervisors with the best performance were selected to participate in the field data collection activities.

\section{Field work}

Thirteen data collection teams, each consisting of one male

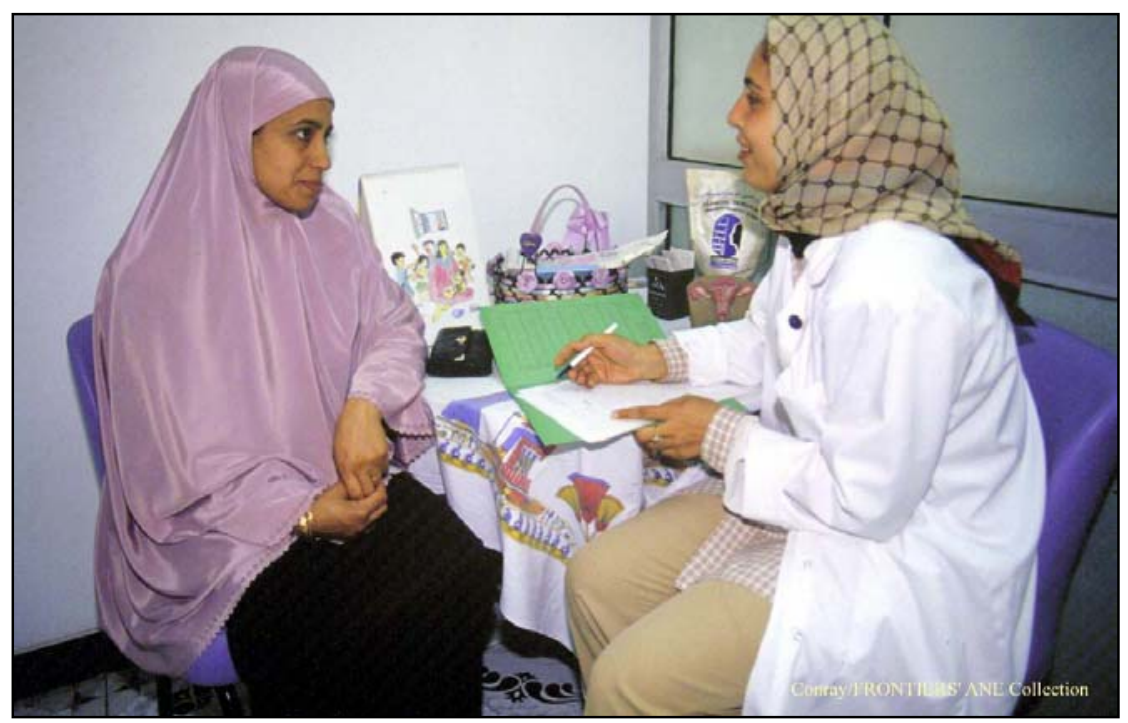
supervisor and two to four female interviewers (based on the number of clinics assigned to each team) were formed. Each team was assigned to work in one or two governorates. One interviewer was assigned to a study site. The interviewer was responsible for conducting client exit interviews, home interviews (for clients who received NORPLANT ${ }^{\circledR}$ service at this clinic) and provider interviews. In addition, the interviewer was responsible for completing the information sheets on client cards. Based on client caseload information and the target number of interviews, each interviewer was instructed to stay between two to four weeks at the clinic to collect data needed. 
The supervisor was responsible for organizing the teamwork; field editing of the completed forms and making sure that the target sample was achieved. In addition, the supervisor was responsible for completing the clinic form. Due to variability in caseload between clinics, gathering the target number of 20 exit interviews for some clinics was difficult. Therefore, data collection was extended in some clinics for an additional week.

Quality control measures were applied throughout the data collection period including the close supervision of data collection procedures. The principle investigator, research coordinator, fieldwork coordinator and Population Council staff made regular visits to the study sites to observe the field work and monitor informed consent procedures. In addition, ten percent of the study sites were randomly selected to compare Table 3: Sampling Results (completed forms) by Type of Health Facility

\begin{tabular}{|l|c|c|c|c|}
\hline Type of Hospital & MOHP & University & Teaching & Total \\
\hline Exit interviews & 572 & 83 & 85 & 740 \\
Home interviews & 500 & 54 & 70 & 624 \\
Physicians interviews & 47 & 11 & 8 & 66 \\
Nurses interviews & 50 & 6 & 8 & 64 \\
MIS client entries checked* & 334 & 52 & 73 & 460 \\
Client's card & 189 & 24 & 63 & 276 \\
& & & & \\
\hline
\end{tabular}

*This number represents matched clients' records (available in both clinic registers and MIS). However, the overall number of MIS client entries checked was 720

the data collected with the clinic's records. Data collection activities began in the second week of October 2000 and lasted for five weeks. Table 3 shows the number of study instruments completed by type of health facility.

\section{FINDINGS}

\section{Clinics Characteristics}

Table 4 presents data on selected characteristics of the study sites by type of facility. The clinics providing NORPLANT ${ }^{\circledR}$ insertion services have on average 4.3 physicians providing family planning services,

Table 4: Study Sites by Type and Selected Characteristics ( $\mathrm{n}=36$ clinics) and close to half are trained on NORPLANT ${ }^{\circledR}$ insertion $(2.3$ physician). The number of physicians who

\begin{tabular}{|l|c|c|c|c|}
\hline Characteristics & $\begin{array}{c}\text { MOHP } \\
(\mathbf{n = 2 9 )}\end{array}$ & $\begin{array}{c}\text { University } \\
(\mathbf{n = 3})\end{array}$ & $\begin{array}{c}\text { Teaching } \\
(\mathbf{n = 4})\end{array}$ & $\begin{array}{c}\text { Total } \\
(\mathbf{n = 3 6})\end{array}$ \\
\hline Mean No. of physicians & 4.2 & 7.0 & 3.0 & 4.3 \\
\hline $\begin{array}{l}\text { Mean No. of physicians trained on } \\
\text { NORPLANT }{ }^{\circledR} \text { Insertion }\end{array}$ & 1.9 & 6.7 & 2.3 & 2.3 \\
\hline $\begin{array}{l}\text { Mean No. of physicians trained on } \\
\text { NORPLANT }\end{array}$ removal & 1.7 & 6.7 & 2.3 & 2.2 \\
\hline Mean No. of family planning nurses & 2.5 & 4.3 & 2.0 & 2.6 \\
\hline $\begin{array}{l}\text { Percent of sites that provide removal } \\
\text { services }\end{array}$ & 69.0 & 100 & 100 & 75.0 \\
\hline
\end{tabular}

Source: Clinic information form

received training on NORPLANT ${ }^{\circledR}$ removal is slightly less (on average 2.2 physician). The average number of nurses involved in family planning service provision (2.6) is lower than the number of physicians. The mean number of physicians and nurses providing NORPLANT ${ }^{\circledR}$ services at the university hospitals is about double the mean number of the same service categories at MOHP 
clinics and teaching hospitals. It may be noted here that, based on available information on number of physicians trained on NORPLANT ${ }^{\circledR}$ insertion, it was found that mean number of insertions during the month of September, 2000 per physician at MOHP clinics (7.5 insertions) was much higher than the comparable mean for physician at university hospitals (3.2) or teaching hospitals (3.0). Removal service is not available in all MOHP clinics (69 percent only), but available in all university and teaching hospitals.

Figure 1 shows the trend of mean monthly NORPLANT ${ }^{\circledR}$ caseload per clinic during the period August 1999 - September 2000 for both insertions and removals. In general, for all the period shown, and all clinics the monthly mean number of insertions per clinic is 11.3 and the median is 9.5 with a Figure 1: Average Monthly Number of NORPLANT® Insertions and Removals range of insertions of 1.8 40.1. Also, the monthly mean number of removals is 1.2 and the median is 0.1 , with a range of removals of 0 - 9.6. Considering clinics by type, the findings indicated that for all the period shown, the monthly mean number of insertions

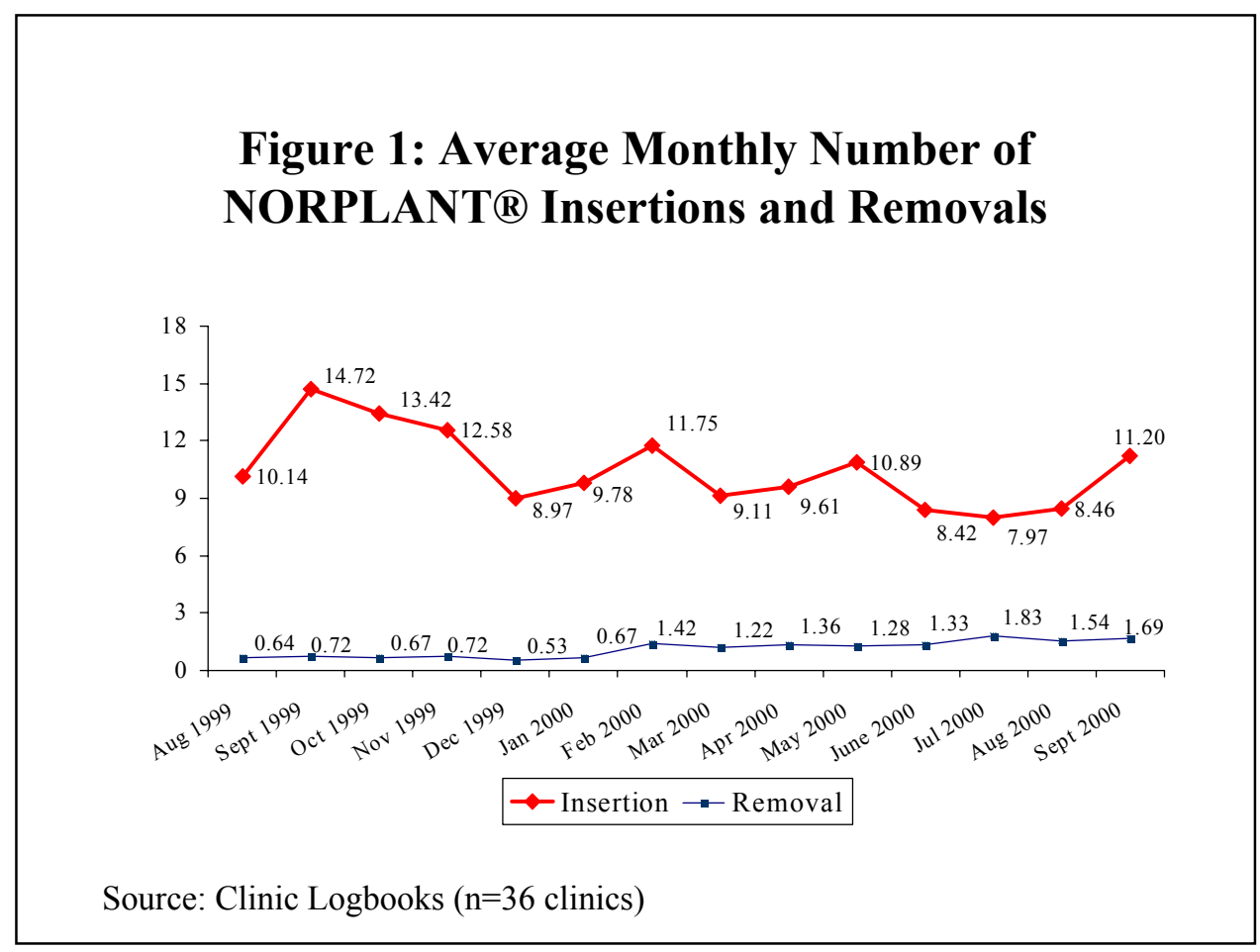
and removals per MOHP clinic is 10.9 and 0.2 respectively. For the university hospital, the comparable means are 12.5 and 6.9, and for the teaching hospital 12.7 and 4.0, respectively.

\section{Selected Socio-demographic Characteristics of Physicians}

Table 5 presents the findings on socio-demographic characteristics of the physicians who provide NORPLANT $^{\circledR}$ services in the study sites. The majority of the physicians are male (62 percent) and more than one-half of them are 40 years old or more (mean age is about 41 years). More than 90 percent of the physicians have attained post-graduate degrees (diploma, master or doctorate degree). In fact, all the university and teaching hospital physicians have attained post-graduate degrees, indicating a high education level overall among physicians who provide NORPLANT ${ }^{\circledR}$ services. On average university hospital physicians have worked about six years in providing NORPLANT ${ }^{\circledR}$ services compared to about three years for teaching hospitals physicians and a year and half for MOHP physicians. 
Table 5: Selected Socio-Demographic Characteristics of Physicians who Provide NORPLANT $^{\circledR}(\mathrm{n}=66)$

\begin{tabular}{|c|c|c|c|c|}
\hline Characteristics & $\begin{array}{c}\text { MOHP } \\
(n=47)\end{array}$ & $\begin{array}{c}\text { University } \\
(n=11)\end{array}$ & $\begin{array}{c}\text { Teaching } \\
(\mathbf{n}=8)\end{array}$ & $\begin{array}{c}\text { Total } \\
(n=66)\end{array}$ \\
\hline Sex & & & & \\
\hline Male & 53.2 & 100 & 63.0 & 62.1 \\
\hline Female & 46.8 & 0.0 & 37.0 & 37.9 \\
\hline \multicolumn{5}{|l|}{ Age } \\
\hline Less than 30 & 2.1 & 18.2 & 0.0 & 4.5 \\
\hline $30-39$ & 29.8 & 72.8 & 25.0 & 36.4 \\
\hline $40+$ & 68.1 & 9.0 & 75.0 & 59.1 \\
\hline mean age & 41.7 & 33.6 & 44.0 & 40.6 \\
\hline \multicolumn{5}{|l|}{ Education (highest degree attained) } \\
\hline University degree & 10.6 & 0.0 & 0.0 & 7.5 \\
\hline Diploma / Master / Ph.D. & 89.4 & 100.0 & 100.0 & 92.5 \\
\hline \multicolumn{5}{|l|}{$\begin{array}{l}\text { Experience with NORPLANT }{ }^{\circledR} \text { service } \\
\text { provision }\end{array}$} \\
\hline $\begin{array}{l}\text { Mean no. of years working in NORPLANT } \\
\text { service provision }\end{array}$ & 1.4 & 5.6 & 2.9 & 2.3 \\
\hline $\begin{array}{l}\text { Received training in NORPLANT } \\
\text { insertion/removal? (yes) }\end{array}$ & 93.6 & 100.0 & 87.5 & 93.9 \\
\hline Need additional training in insertion? (yes) & 27.2 & 9.1 & 12.5 & 22.7 \\
\hline Need additional training in removal? (yes) & 61.7 & 18.2 & 50.0 & 53.0 \\
\hline
\end{tabular}

Source: physician interview

Physicians were asked about the training they received in family planning and reproductive health as well as in NORPLANT ${ }^{\circledR}$ insertion and removal. They were also asked if they thought that the training they received in NORPLANT ${ }^{\circledR}$ insertion and removal was sufficient. Almost all the physicians indicated that they received training in family planning and reproductive health areas. Approximately 94 percent of the physicians who provide NORPLANT ${ }^{\circledR}$ services have attended training courses on the insertion and removal of NORPLANT ${ }^{\circledR}$ but physicians in teaching hospitals were less likely to be fully trained. Overall about one-half of the physicians who provide NORPLANT $^{\circledR}$ reported a felt need for additional training in NORPLANT ${ }^{\circledR}$ removal.

\section{Selected Socio-Demographic Characteristics of Nurses}

Table 6 presents data on selected socio-demographic characteristics of nurses. About two-thirds of the nurses are less than 40 years old, with a mean age of 34 years. The majority of them received nursing school level ( 88 percent), which requires a minimum of 12 years of schooling. Overall, nurses reported working in NORPLANT ${ }^{\circledR}$ service provision for an average of almost two and onehalf years. However, university hospital nurses had more experience in NORPLANT ${ }^{\circledR}$ service provision (mean number of years is 8.3 ). These nurses are also relatively older and more qualified compared to MOHP and teaching hospitals nurses. Almost all of the nurses have received training in family planning and the large majority (79 percent) have received training in NORPLANT ${ }^{\circledR}$ service provision. 
Table 6: Selected socio-demographic characteristics of nurses $(n=64)$

\begin{tabular}{|c|c|c|c|c|}
\hline \multirow[b]{2}{*}{ Characteristics } & \multicolumn{4}{|c|}{ Percent } \\
\hline & $\begin{array}{c}\text { MOHP } \\
(n=50)\end{array}$ & $\begin{array}{c}\text { University } \\
(\mathrm{n}=6)\end{array}$ & $\begin{array}{c}\text { Teaching } \\
(\mathrm{n}=8)\end{array}$ & $\begin{array}{c}\text { Total } \\
(n=64)\end{array}$ \\
\hline Age & & & & \\
\hline Less than 25 & 20.0 & 0.0 & 12.5 & 17.2 \\
\hline $25-30$ & 22.0 & 16.7 & 25.0 & 21.9 \\
\hline $30-39$ & 26.0 & 16.7 & 12.5 & 23.4 \\
\hline $40+$ & 32.0 & 66.7 & 50.0 & 37.5 \\
\hline Mean age & 33.5 & 39.7 & 35.4 & 34.3 \\
\hline Education (highest degree attained) & & & & \\
\hline Nursing school & 94.0 & 66.7 & 62.5 & 87.5 \\
\hline Nursing school + one year specialization & 6.0 & 33.3 & 37.5 & 12.5 \\
\hline $\begin{array}{l}\text { Years working in NORPLANT }{ }^{\circledR} \text { service } \\
\text { provision }\end{array}$ & 26.0 & 0.0 & 0.0 & 20.3 \\
\hline Less than one year & 30.0 & 0.0 & 0.0 & 23.4 \\
\hline 1 & 8.0 & 16.7 & 25.0 & 10.9 \\
\hline 2 & 26.0 & 0.0 & 62.5 & 28.1 \\
\hline 3 & 10.0 & 83.3 & 12.5 & 17.3 \\
\hline 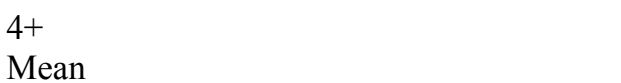 & 1.6 & 8.3 & 2.9 & 2.4 \\
\hline $\begin{array}{l}\text { Received training in family planning and } \\
\text { reproductive health? } \\
\text { Yes }\end{array}$ & 98.0 & 100.0 & 100.0 & 98.4 \\
\hline $\begin{array}{l}\text { Number of training workshops attended } \\
1-2\end{array}$ & 44.9 & 0.0 & 25.0 & 28.1 \\
\hline 3 & 26.5 & 16.7 & 75.0 & 31.7 \\
\hline $4+$ & 28.6 & 83.3 & 0.0 & 30.2 \\
\hline Mean & 3.0 & 4.8 & 2.6 & 3.1 \\
\hline Topics of training workshops & & & & \\
\hline FP methods & 100.0 & 100.0 & 100.0 & 100.0 \\
\hline NORPLANT $^{\circledR}$ & 75.5 & 100.0 & 87.5 & 79.4 \\
\hline Reproductive Health & 55.1 & 100.0 & 75.0 & 61.9 \\
\hline TOT & 28.6 & 83.3 & 0.0 & 30.2 \\
\hline Registration & 8.2 & 50.0 & 0.0 & 11.1 \\
\hline
\end{tabular}

Source: nurse interview

\section{Selected Demographic and Socio-economic Characteristics of NORPLANT ${ }^{\circledR}$ Users}

Table 7 presents data on selected demographic and socio-economic characteristics of new and continuing users of NORPLANT ${ }^{\circledR}$ obtained through exit interviews and home visits (respectively). The data show that new users are on average younger (mean age $=31.4$ years) than continuing users (mean age $=34.3$ years) and the difference is significant $(\mathrm{p}<0.05)$. Both groups of women had nearly the same mean number of living children (slightly more than four). On average, the mean age of youngest child was 2.8 years for new users which is significantly lower than the mean age of 4.8 years for continuing users (the difference is significant, $\mathrm{p}<0.05$ ).

It should be noted that the study findings reflected a higher percentage of women who use NORPLANT $^{\circledR}$ for spacing purposes among new users (14 percent) than continuing users (only 9 percent) (not shown in the table). This may explain the difference in the mean age of youngest child. In addition, the mean age of youngest child for the continuing users refers to date of interview rather than date of insertion. 
It is interesting to note that continuing users were on average better educated, married to husbands who were also relatively better educated and were more likely to work for cash (however, only difference in work status is significant, $\mathrm{p}<0.05)$. The results from the Standard of Living Index (SLI) further corroborate this finding (see the bottom of Table 7 for description of constructing the SLI index).

The mean SLI value for continuing users is 12.5 compared to 11.9 among new users (the difference is significant, $\mathrm{p}<0.05$ ). This finding may reflect the influence of making NORPLANT $^{\circledR}$ free of charge among women belonging to lower socio-economic levels.

\section{Client Record System}

\section{Audit}

The study compared information on clients
Table 7: Selected Socio-Demographic and Economic Characteristics of New and Continuing Users of NORPLANT ${ }^{\circledR}$

\begin{tabular}{|c|c|c|}
\hline \multirow[b]{2}{*}{ Characteristics } & \multicolumn{2}{|c|}{ Percent } \\
\hline & $\begin{array}{c}\text { New users } \\
(n=740)\end{array}$ & $\begin{array}{l}\text { Continuing users } \\
(n=624)\end{array}$ \\
\hline Age $^{1}$ & & \\
\hline$<25$ & 14.2 & 3.8 \\
\hline $25-34$ & 50.5 & 45.5 \\
\hline $35+$ & 35.3 & 50.6 \\
\hline Mean age & 31.4 & 34.3 \\
\hline Living children & & \\
\hline 1 & 2.1 & 1.1 \\
\hline $2-3$ & 43.6 & 35.9 \\
\hline $4+$ & 54.3 & 63.0 \\
\hline Mean & 4.1 & 4.2 \\
\hline Age of youngest child $^{1}$ & & \\
\hline Less than a year & 23.7 & 4.8 \\
\hline 1 & 14.2 & 13.0 \\
\hline 2 & 13.4 & 16.0 \\
\hline $3+$ & 48.7 & 66.2 \\
\hline Mean & 2.8 & 4.8 \\
\hline Education & & \\
\hline Illiterate & 52.0 & 52.5 \\
\hline Read and write & 12.7 & 11.6 \\
\hline Primary/preparatory & 16.6 & 14.0 \\
\hline Secondary and above & 18.7 & 22.0 \\
\hline Work status $^{1}$ & & \\
\hline Not working & 84.2 & 76.3 \\
\hline Working/no cash & 4.6 & 6.3 \\
\hline Working for cash & 11.2 & 17.5 \\
\hline Husband education & & \\
\hline Illiterate & 33.6 & 30.0 \\
\hline Read and write & 16.1 & 17.0 \\
\hline Primary/preparatory & 18.5 & 20.8 \\
\hline Secondary and above & 31.8 & 32.2 \\
\hline Standard of Living Index (SLI) ${ }^{1,2}$ & & \\
\hline Low $(2-10)$ & 31.2 & 20.7 \\
\hline Medium (11-13) & 36.5 & 40.4 \\
\hline High (14-25) & 32.3 & 38.9 \\
\hline Mean SLI & 11.9 & 12.5 \\
\hline
\end{tabular}

Source: client exit and home interviews

1. Differences are significant $(\mathrm{P}<0.05)$

2. A composite index for socio-economic status of the household. It includes a set of variables related to housing conditions and ownership of consumer durables of the woman's household. The housing conditions included in the index and their scoring are as follows: one point for each room in the household; one point for piped drinking water, modern flush toilet, electricity and a cement/ cement tile floor; and two points if the floor material was wood parquets, ceramic tiles, marble or wall-to-wall carpet. In addition, one point was given for ownership of each of the following items: a radio with cassette recorder; a black and white television; a color television; a video; a telephone; an electric fan; a water heater, a refrigerator, a washing machine, a bicycle, a private car/ motorcycle, transport equipment, farm or other land and livestock. Based on data of exit and home interviews, the value of this index ranged between 2-25

obtained from the clinics' client records (in clinic registries and log books) to the actual client records available at the MOHP MIS central level to assess the reliability and completeness of the recording system. Table 8 summarizes these findings. Records that existed in both clinic registers and MIS (regardless of the accuracy of client's information) represented about two-thirds (64\%) of the cases. One-third of clients' records were available in clinics' registers but not in the MIS. The majority of this category was found at MOHP facilities. Three percent of the clients records were 
available in the central MIS

but not in the clinics, (about

13 percent of university

hospitals' records fall in this category).

\section{Accuracy of client}

records information between

\section{clinic and central MIS}

Table 8: Matching Client Records at MIS Central Level and Clinic Level

\begin{tabular}{|l|l|l|l|l|}
\hline & $\begin{array}{l}\text { MOHP } \\
(\mathbf{n = 5 8 0})\end{array}$ & $\begin{array}{l}\text { University } \\
(\mathbf{n = 6 0 )}\end{array}$ & $\begin{array}{l}\text { Teaching } \\
(\mathbf{n = 8 0})\end{array}$ & $\begin{array}{l}\text { Total } \\
(\mathbf{n = 7 2 0})\end{array}$ \\
\hline $\begin{array}{l}\text { Client records exist in } \\
\text { clinics and MIS }\end{array}$ & 57.9 & 86.7 & 91.3 & 64.0 \\
$\begin{array}{l}\text { Client records exist in } \\
\text { clinics but not in MIS }\end{array}$ & 40.0 & 0.0 & 7.5 & 33.0 \\
$\begin{array}{l}\text { Client records exist in } \\
\text { MIS but not in clinics }\end{array}$ & 2.1 & 13.3 & 1.2 & 3.0 \\
\hline
\end{tabular}

Source: central/MIS and clinic registers

A review of accuracy of the information was conducted for client records that existed in both the clinic and the central MIS ( $\mathrm{n}=460)$. Each client record included 19 information items. These

indicators were compared

in the two sources

(clinics' registers and

MIS), and each item was

given a score of 1 in case

of "perfect fit" and 0 in

case of "no fit." Figure 2

presents the findings of

these comparisons for

only selected information

items. The mean of the

degree of concordance

between the two sources

of data is high for the
Figure 2: Agreement on Key Indicators Between Client Record Information at MIS Central Level and Clinic Level

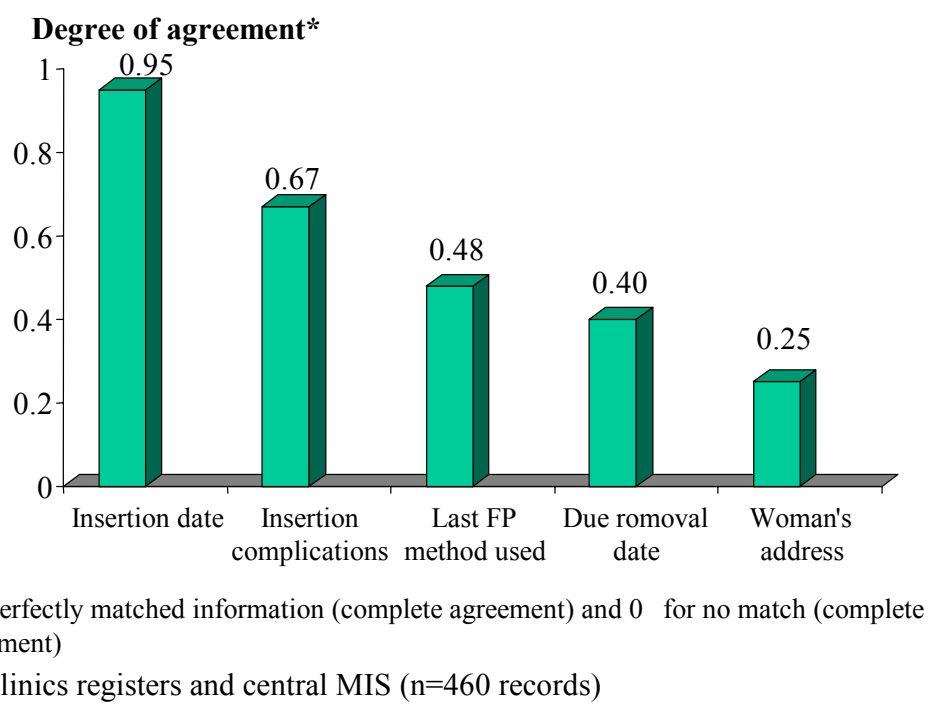

insertion date (0.95), moderate for the insertion complications (0.67), low for removal date $(0.4)$ and last family planning used (0.48), and very low for woman's address (0.25).

\section{Accuracy of the clients' addresses}

Each facility that provides NORPLANT ${ }^{\circledR}$ should keep complete and correct information about the clients' addresses and the addresses of one of their relatives in order to ensure follow-up care, including removal of the implants. The availability of this information is critical for clients who fail to return to clinics for removal at the end of NORPLANT ${ }^{\circledR}$ use duration. Table 2 (presented earlier) indicates that only about 56 percent of the continuing users selected at random for the home interview were actually reached using the locator information on the client records. An additional 37 percent of NORPLANT ${ }^{\circledR}$ clients could not be located because their addresses were incomplete. Furthermore, in the majority of clients' records information on the relative's address was not collected. In only 3 percent of the cases the address was complete and correct but it was not 
possible to interview the women. This represents cases that implicitly refused to give consent for follow-up contact, and it is noted to be a very small proportion of the total sample.

\section{Existence of the clients' cards}

The MOHP Systems Development

Project established a follow-up

system for all family planning

clients, including NORPLANT ${ }^{\circledR}$

users. Client who receive a family

planning method are given a card

to record the dates of follow-up

visits. To assess the accuracy of

information of the client follow-up
Table 9: Client Follow-up Cards: Receipt by NORPLANT ${ }^{\circledR}$ Users and Agreement of Information with Clinic Records

\begin{tabular}{|l|c|}
\hline \multicolumn{1}{|c|}{ Item } & Percent \\
\hline Received a card from the clinic? (n=624) & \\
Yes, and I still keep it & 45 \\
Yes, but later was lost & 40 \\
No & 15 \\
\hline Matched Items (agreement) $\boldsymbol{*},(\mathbf{n = 2 6 7 )}$ & \\
Client serial number & 0.88 \\
Year of insertion & 0.98 \\
First follow up scheduled visit date & 0.60 \\
First follow up actual visit date & 0.71 \\
\hline
\end{tabular}

Source: home interviews and clinics' logbooks

$*$ perfect agreement $=1.00$, perfect disagreement $=0.00$ card for NORPLANT ${ }^{\circledR}$ users, interviewers were instructed to ask each continuing user during the home interview if she was given this card. If she answered yes, the interviewer requested to see the card and to transcribe all the information recorded on it to a form designed for this purpose. Field supervisors recorded the comparable information for the same woman from the clinic register on the

same form. Information

from both sources was

then compared and

discrepancies identified

(Table 9). The table shows

that 45 percent of

continuing NORPLANT ${ }^{\circledR}$

users received a card and

were still keeping it. Two-

fifths $(40 \%)$ received the

follow-up card but it was

later lost. In 15 percent of

cases, women said that

\section{Figure 3: Decision Making Roles on FP Methods as Reported by NORPLANT ${ }^{\circledR}$ Physicians}

\section{Who decides about the appropriate FP method?}

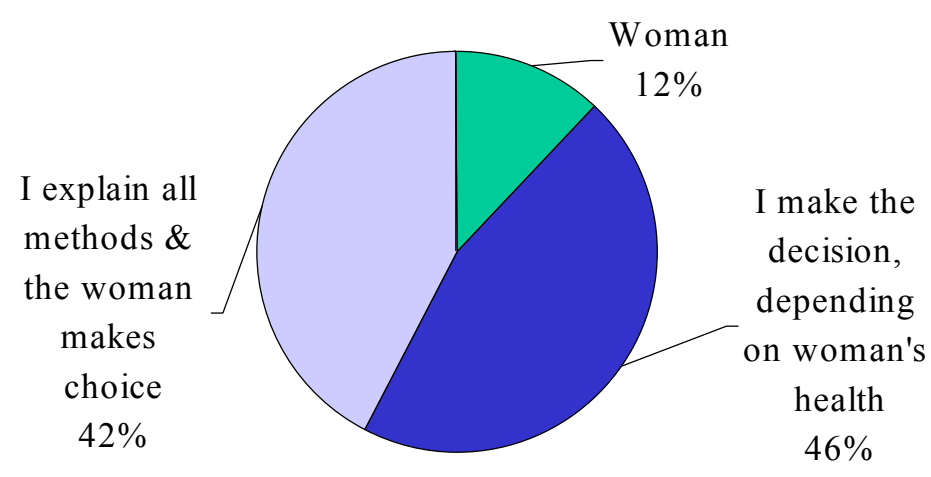

Source: physician interview $(\mathrm{n}=66)$

they did not receive a card. Cases in which the card was available also indicated some discrepancies in accuracy of information recorded on the card, but overall the information on the client card corresponded with the clinic records particularly on the year of insertion. 
Physicians were asked

about who decides which family planning method is most appropriate for a woman to use (Figure 3).

Two-fifths of the physicians $(42 \%)$ indicated that they explain to the client all family planning methods and talk with them about their health conditions, and then the woman makes the choice. An

\section{Figure 4: What are the Advantages of NORPLANT®?}

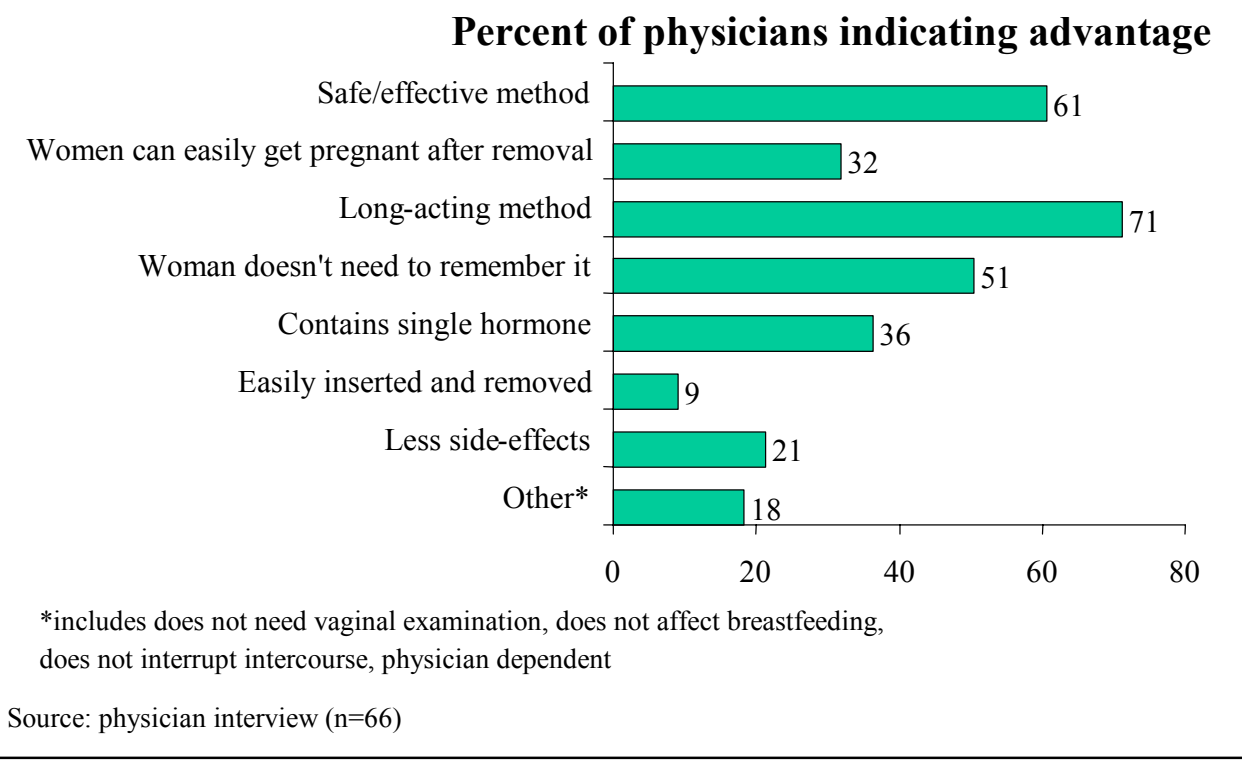

additional 12 percent stated that the woman makes the choice. Taken together these findings indicate that slightly over one-half of the physicians report some degree of choice-making authority rests with the client. Unfortunately, the remaining $46 \%$ of the physicians claim full responsibility for selecting the client's family planning method.

Physicians were asked about their views about NORPLANT ${ }^{\circledR}$ advantages and disadvantages. The advantages most frequently mentioned were that NORPLANT ${ }^{\circledR}$ is a long-acting method (reported by 71 percent) and that it is a safe and effective method (61

\section{Figure 5: What are the Disadvantages of NORPLANT®?}

\section{Percent of physicians indicating disadvantage}

Nausea and blurring of vision Weight gain Surgical procedure Difficulty of removal Severe headache Severe bleeding Menstrual cycle disturbance Pain at site of insertion None
Other*
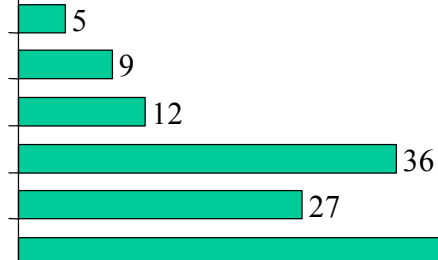
42

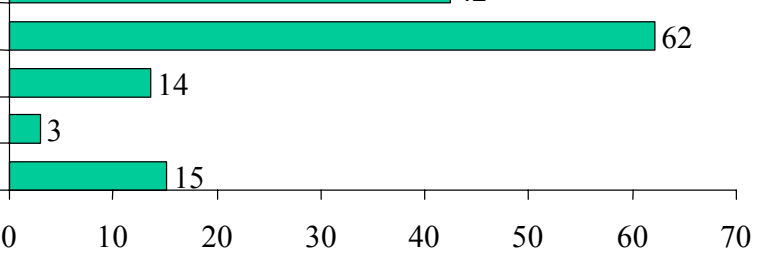

*Includes: affects libido, visible in arm, causes illness, affects breastfeeding if used before 6 months after delivery, possibility to select inappropriate candidates

Source: physician interview $(\mathrm{n}=66)$

percent) (Figure 4). About one-half of physicians mentioned that women do not need to remember doing anything to avoid pregnancy, like taking a pill daily. The most frequently reported disadvantage of NORPLANT ${ }^{\circledR}$ is that it causes menstrual cycle disturbance (reported by $62 \%$ of physicians) (see Figure 5). The next most frequently mentioned disadvantage is that it sometimes 
causes severe bleeding (42\%), followed by difficulty of removal (36\%). Other disadvantages mentioned were NORPLANT ${ }^{\circledR}$ causes severe headache $(27 \%)$, pain at site of insertion $(14 \%)$, weight gain (9\%) and that its insertion and removal required a surgical procedure $(12 \%)$. In a separate question (results not shown in Figure 5), physicians were asked about the side effects of NORPLANT ${ }^{\circledR}$. The responses indicate a moderate level of awareness or knowledge. The majority of them mentioned menstrual cycle disturbances $(86 \%)$. About one-half mentioned headache (60\%), weight gain (50\%) and bleeding (49\%).

Both physicians and nurses were asked about the type of information they provide to women who come to have NORPLANT ${ }^{\circledR}$ inserted (Figure 6). The most commonly cited information points are duration of use, advantages and side-effects. However, fewer physicians $(38$ percent) and nurses (64 percent) mentioned the number of NORPLANT ${ }^{\circledR}$ rods and insertion procedure (64 and 53 percent). Only $24 \%$ of the physicians mentioned removal procedures.

Figure 7 presents the results on physicians' knowledge about the contraindications for NORPLANT ${ }^{\circledR}$ use. These results reflect lack of consensus among physicians about NORPLANT ${ }^{\circledR}$ contraindication and suggest the need for more training of physicians on

\section{Figure 6: What is the Information you Provide to Women who Require a NORPLANT ${ }^{\circledR}$ ?}

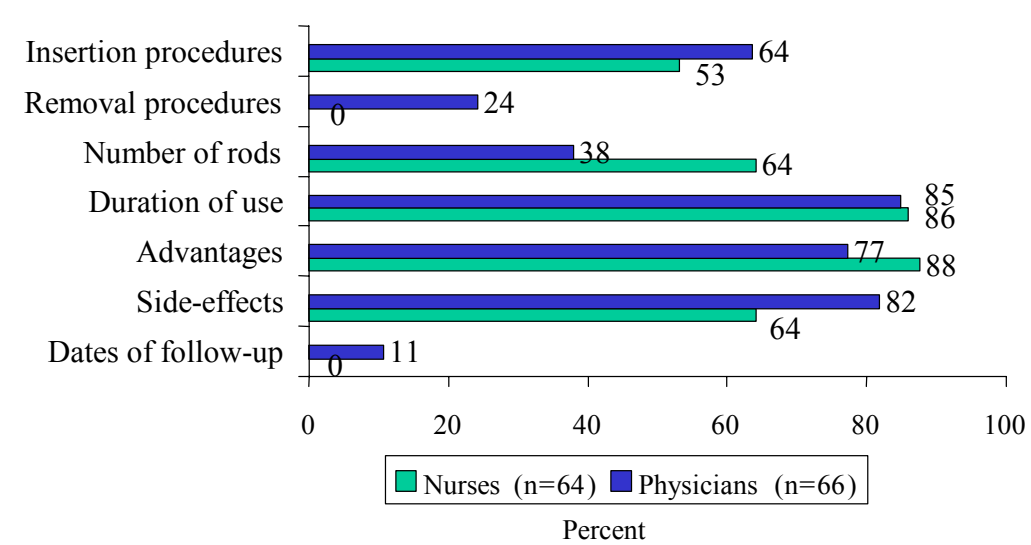

Source: physician and nurse interviews

\section{Figure 7 : What are the Contraindications of NORPLANT® Use?}

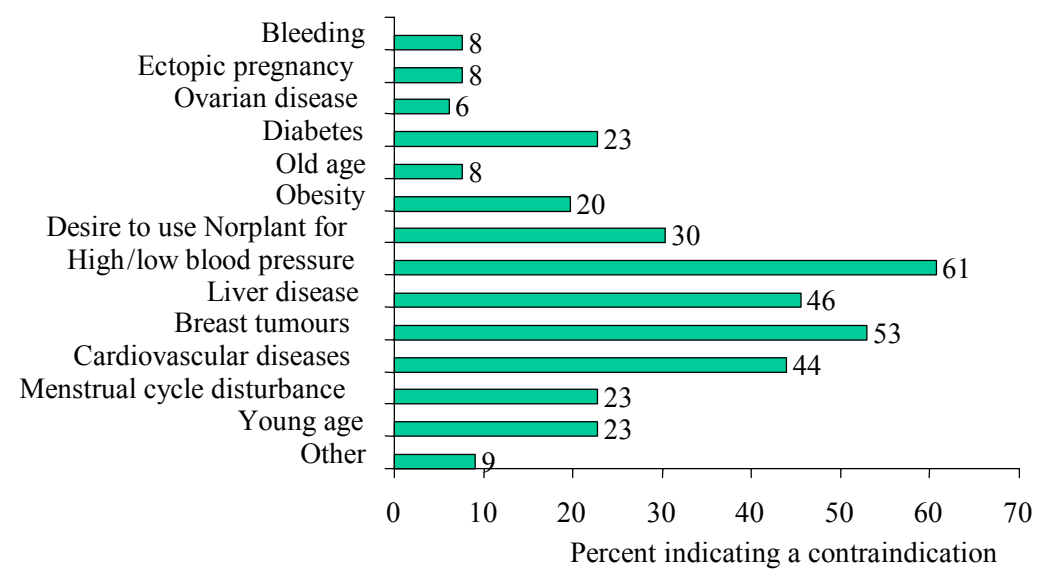

Source: physician interview $(n=66)$ 
this issue. With the exception to the presence of tumors of the breast (cited by $53 \%$ of the physicians) and experience of high/low blood pressure (cited by $61 \%$ of the physicians) other causes were reported by a low percentage of physicians, and inaccurate or false contraindications were provided.

\section{Selected Aspects of Service Provision and Related Performance Appraisal}

\section{Experience with \\ NORPLANT ${ }^{\circledR}$ removal}

Physicians who ever

removed NORPLANT ${ }^{\circledR}$

$(n=51)$ were asked if

they have ever faced

difficulties in

NORPLANT ${ }^{\circledR}$ removal.

About two-fifths (43\%)

responded affirmatively

(Figure 8). The most

frequent problems met
Figure 8: Difficulties in Removal of NORPLANT® Implants

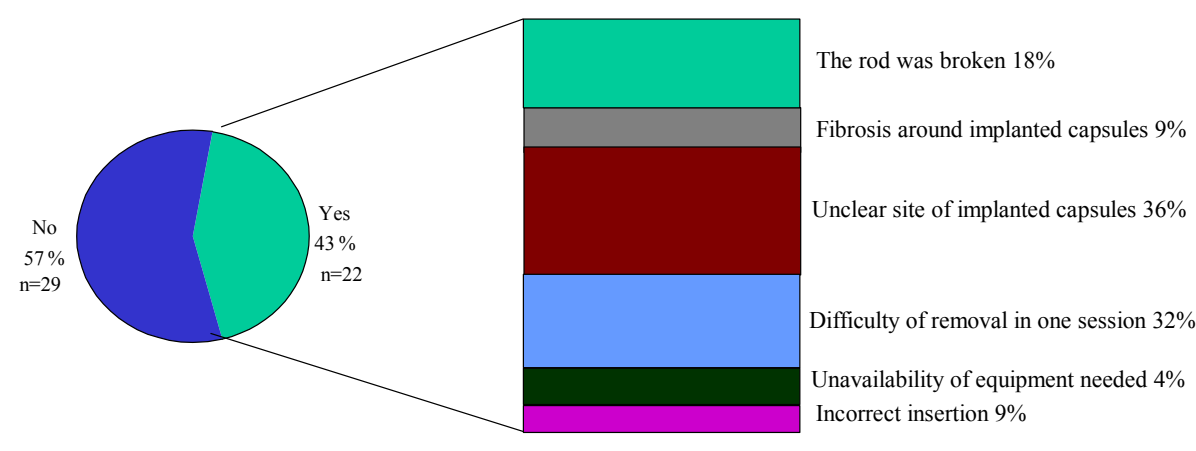

Have you faced any removal problems?
$(\mathrm{n}=\mathbf{5 1})$

Type of removal problems faced $(n=22)$

were that the site of implanted capsules was not clear (36\%) and difficulty of removing all rods in one session (32\%). The latter difficulty implies that more than one visit to the clinic was needed by the woman to completely remove which is a cause for concern. Other difficulties faced were that the rod was broken during removal (18\%) and incorrect insertion of the capsules and the presence of fibrosis around implanted capsules (reported each by 9 percent of physicians who faced removal problems).

\section{Figure 9: What are the Infection Control Procedures that Should be Followed During NORPLANT ${ }^{\circledR}$ Insertion/Removal?}

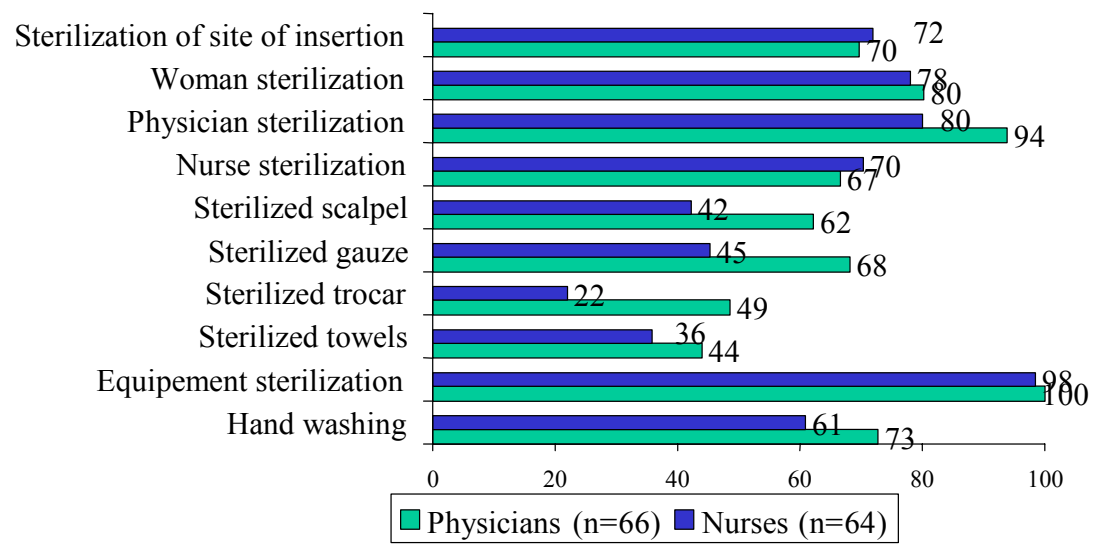

Source: physician and nurse interviews 
An important aspect of safe provision of NORPLANT ${ }^{\circledR}$ services is care given to infection control measures during insertion and removal procedures. Figure 9 presents information on how both physicians and nurses reported they manage infection prevention. Health care providers placed high importance on equipment sterilization as well as physician and woman sterile practices. Other infection control procedures reported by at least two-thirds of the study's physicians and nurses included sterilization of the site of insertion, nurse

\section{Figure 10: Follow-up Care Provided to Women who Inserted NORPLANT®}

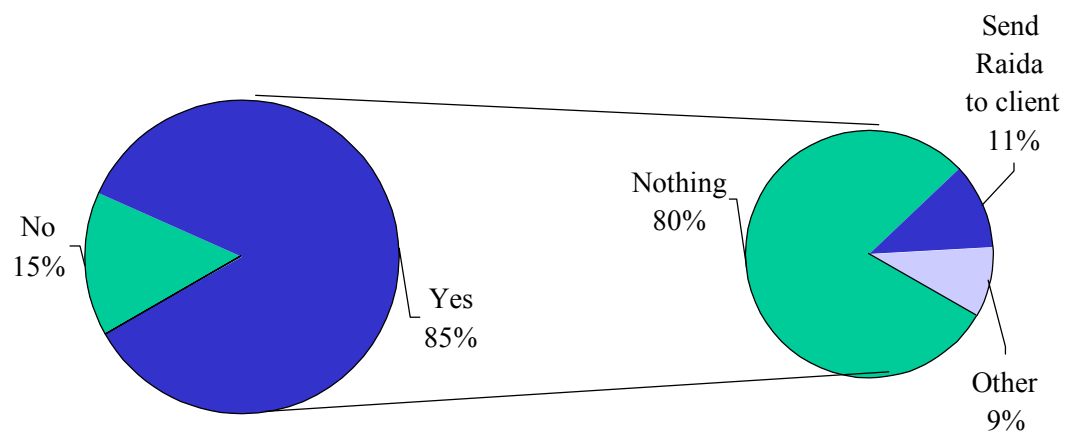

Is there a follow-up system at this clinic for women who inserted Norplant? $(n=66)$

What happens if the woman doesn't visit the clinic for due follow-up visit $(\mathrm{n}=54)$

sterilization and hand washing. Patterns of responses given on infection control procedures seem to be more or less the same for both physicians and nurses.

Since NORPLANT ${ }^{\circledR}$ is a provider dependent method, it is important that the health care system ensure health care providers follow up to ensure that users have NORPLANT ${ }^{\circledR}$ removed or replaced when the implants becomes no longer effective. Figure 10 shows that the majority of physicians indicated that their clinics maintain a follow-up system for women who inserted NORPLANT ${ }^{\circledR}$ In fact, this system primarily involves the use of follow-up cards with scheduled dates for follow-up visits to the clinics (which $40 \%$ of the continuing users reported losing, Table 9).

There appears to be an overreliance on this system, when physicians were asked about

\section{Figure 11: NORPLANT® Shortages}
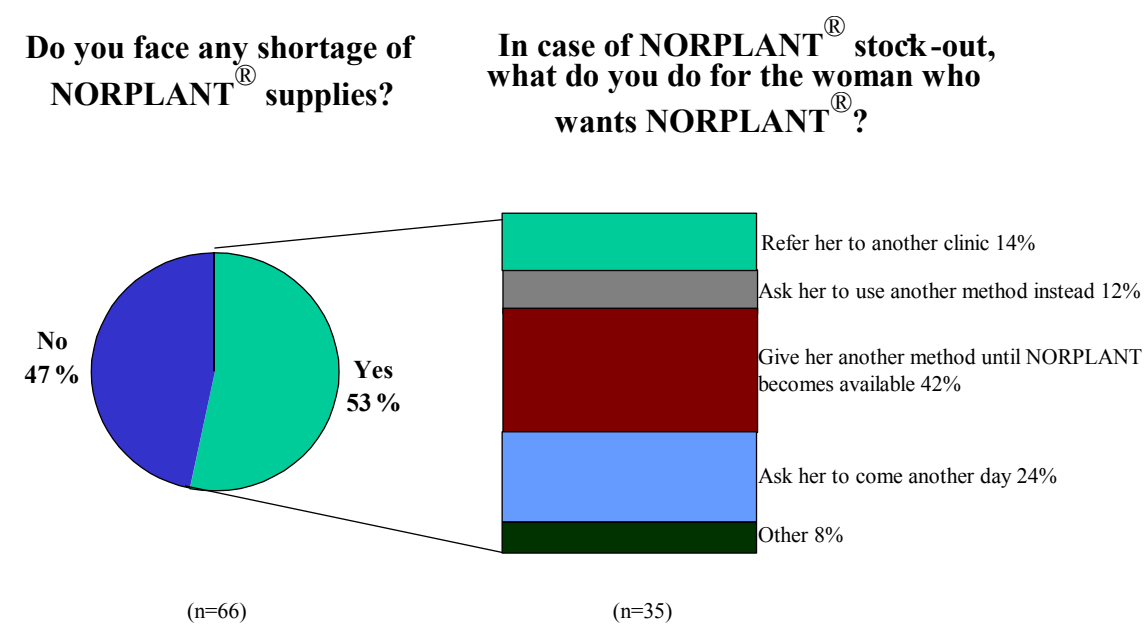

Source: physician interview

what happens if a woman doesn't visit the clinic for her due follow-up visit, about four-fifths of physicians $(80 \%)$ reported that there is no mechanism in place to do home visits for those women. 
This means that women who may forget due removal date/end of NORPLANT ${ }^{\circledR}$ effective use duration will not be contacted by clinic staff to be advised for removal. About one-tenth of physicians, however, reported that usually the clinic sends a Raida (community outreach worker) to the woman's home to remind her about the due follow-up visit.

Figure 11 presents data on the availability of NORPLANT ${ }^{\circledR}$ supplies as reported by physicians. About one-half of physicians indicated that they sometimes experience a shortage of NORPLANT ${ }^{\circledR}$ supplies. When asked what they do in this situation if a woman requests NORPLANT ${ }^{\circledR}$ insertion, about two-fifths reported that they give the woman another method until NORPLANT ${ }^{\circledR}$ supplies become available. An additional 12 percent said they ask the woman to use another method instead of NORPLANT ${ }^{\circledR}$. About one-fourth of the physicians reported that they ask the woman to come to the clinic later (another day) when NORPLANT ${ }^{\circledR}$ will be available. About $14 \%$ of the physicians, however, reported that they refer the woman to another clinic, if they think NORPLANT ${ }^{\circledR}$ supplies are available there.

\section{Promotion of NORPLANT ${ }^{\circledR}$}

This study examined how NORPLANT ${ }^{\circledR}$ are promoted or encouraged (see Figure 12). Service providers were asked a set of questions on whether or not they receive cash incentives for NORPLANT $^{\circledR}$ insertion and the level of these incentives. A small percentage of physicians and nurses (23 and 13 percent, respectively) reported that they receive cash incentives for NORPLANT $^{\circledR}$ insertion. Among this group, about one-half of physicians and one-third of nurses think that the level of cash incentives received is appropriate. For other service providers who thought that the level of incentives is not appropriate, they were asked about their perception of the appropriate level of incentives. The average cash incentive payment proposed by physicians for physicians was LE 327 per month and for nurses was LE 152 per month.

\section{Figure 12: Mechanisms for the Promotion of NORPLANT ${ }^{\circledR}$ Services}

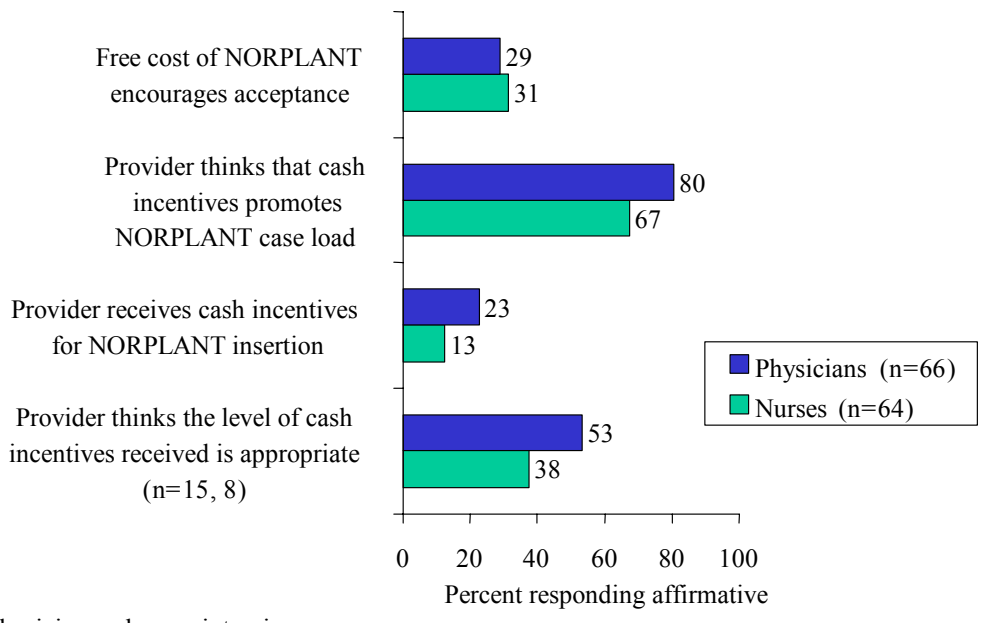

With regard to nurses, they proposed an average incentive payment for physicians of LE 150 and 
for nurses LE 84 (not shown). In general, for all physicians and nurses interviewed, the majority report that monetary incentives could contribute to increase NORPLANT ${ }^{\circledR}$ insertion caseload (80\% of physicians and $67 \%$ of nurses).

It may be noted here that, according to MOHP policy for incentives, women requesting NORPLANT $^{\circledR}$ insertion were originally asked to pay LE 20 for the method. This amount was distributed among service providers working in NORPLANT ${ }^{\circledR}$ services. However, as indicated earlier, MOHP is now offering NORPLANT ${ }^{\circledR}$ free of charge, but still the same amount for each NORPLANT $^{\circledR}$ set inserted (LE 20) is distributed to service providers as follows: 3 percent for administrative staff, and the rest is divided among 60 percent for physicians and 40 percent for nurses and Raida Rifia (social workers).

\section{Figure 13: What are the Five most Important Problems in NORPLANT ${ }^{\circledR}$ Service Provision*?}

\section{Physicians}

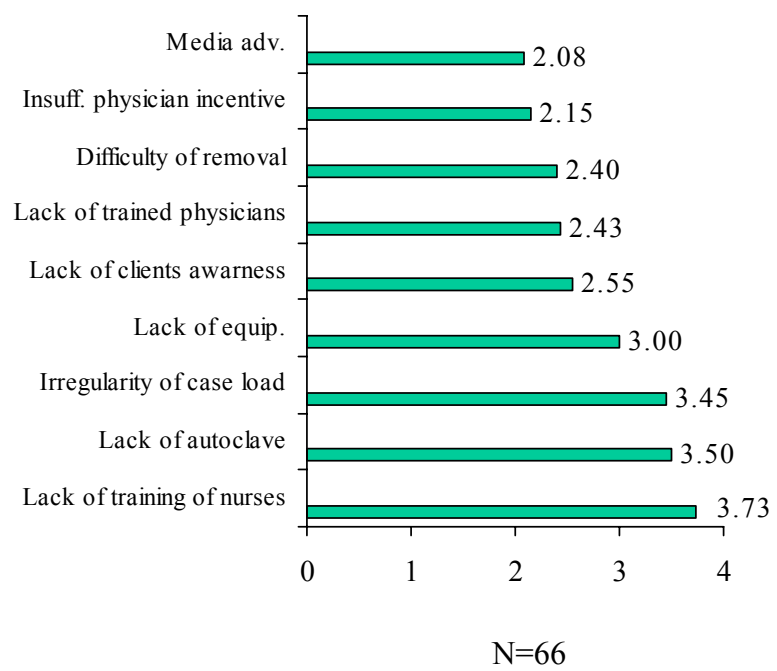

Nurses

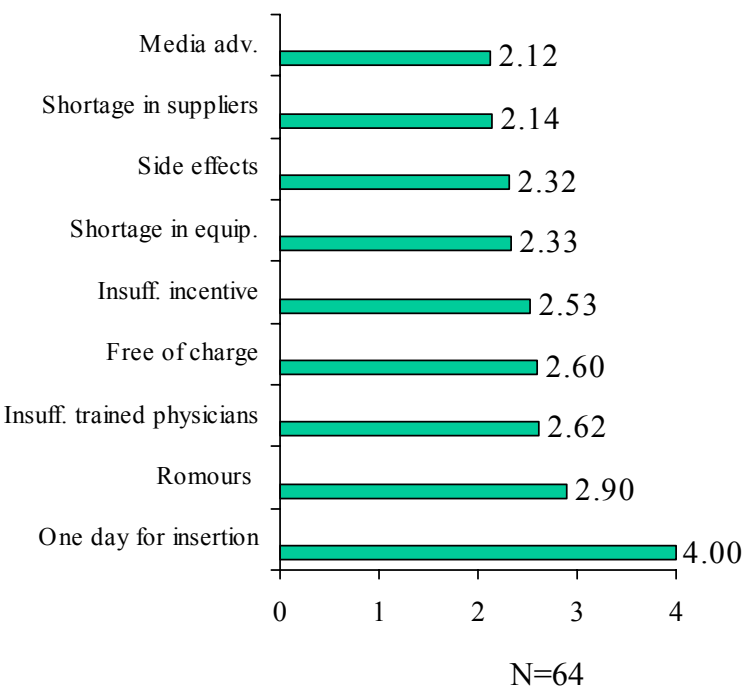

*A lower value for statements shown indicates higher importance to respondents

Source: Physician and nurse interviews 
Finally, physicians and nurses were asked about their views about the five most important problems in NORPLANT ${ }^{\circledR}$ service provision program. Figure 13 shows their responses. Both physicians and

nurses think that the most

important problem is the lack of

media advertising about

NORPLANT $^{\circledR}$. Though

priorities given by physicians

and nurses on NORPLANT ${ }^{\circledR}$

program problems differed, the

type of problems reported were

more or less the same. Problems

reported included the need for

more training of service

providers, lack of NORPLANT ${ }^{\circledR}$
Table 10: Source of Information on NORPLANT ${ }^{\circledR}$ among New Users $(n=740)$

\begin{tabular}{|c|c|}
\hline & Percent \\
\hline $\begin{array}{l}\text { Did you know about NORPLANT }{ }^{\circledR} \text { before use? } \\
\text { Yes }\end{array}$ & 93.6 \\
\hline $\begin{array}{l}\text { Source of information } \\
\text { Physician/nurse } \\
\text { Mass media } \\
\text { Relatives } \\
\text { Friends/neighbors } \\
\text { Others }\end{array}$ & $\begin{array}{r}18.4 \\
24.9 \\
19.7 \\
34.7 \\
2.3\end{array}$ \\
\hline $\begin{array}{l}\text { Did you know source of NORPLANT }{ }^{\circledR} \text { before use? } \\
\text { Yes } \\
\text { Source known }(\mathbf{n}=\mathbf{6 7 5}) \\
\text { MOHP facility } \\
\text { University hospital } \\
\text { Teaching hospital } \\
\text { Other }\end{array}$ & $\begin{array}{r}91.2 \\
79.9 \\
19.7 \\
10.5 \\
9.9\end{array}$ \\
\hline
\end{tabular}

Source: client exit interview

supplies, lack of equipment needed, and insufficient provider incentives.

Clients' knowledge about NORPLANT ${ }^{\circledR}$ and satisfaction with NORPLANT ${ }^{\circledR}$ services

Table 10 presents data on sources of information on NORPLANT ${ }^{\circledR}$ as reported by new users.

Almost all of the new users (94\%) knew about NORPLANT ${ }^{\circledR}$ before they came to the clinic to have it inserted. More than one-half knew about NORPLANT ${ }^{\circledR}$ through "word of mouth" (e.g., satisfied relatives, friends or neighbors using NORPLANT ${ }^{\circledR}$ ). Mass media was reported by about one-fourth of the new users as their source of information. About $18 \%$ of the new users learned about

NORPLANT ${ }^{\circledR}$ first from the

health care provider

(physicians/nurses) but not

necessarily on the day of

insertion. The new users of

NORPLANT $^{\circledR}$ were asked if

they learned about sources of

NORPLANT $^{\circledR}$ before use. The majority (91\%) said "yes."

MOHP health facilities were

most often reported by women

as their source $(80 \%)$.

\section{Figure 14: Previous FP Method Used among New NORPLANT® Users}

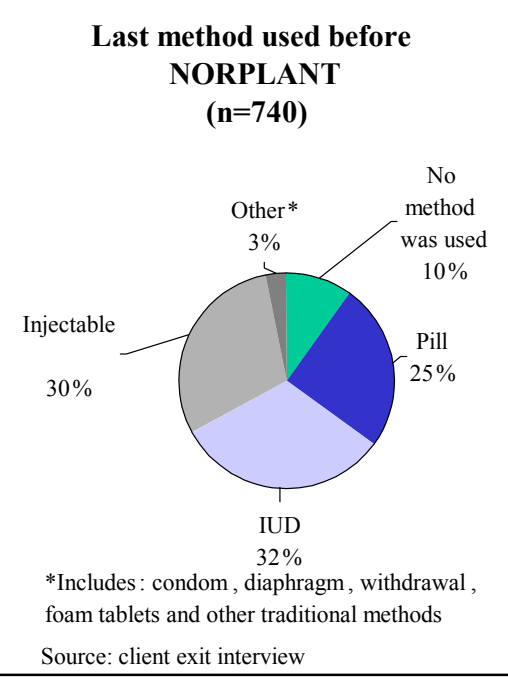

Reasons for discontinuing last method used $(n=669)$

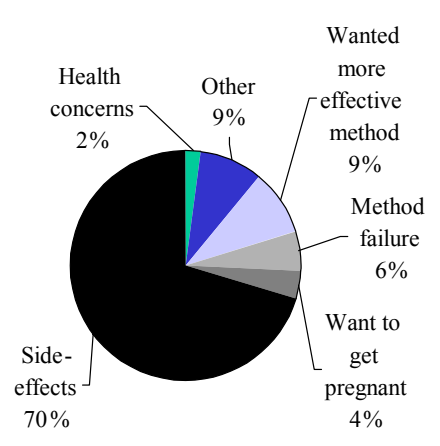

foam tablets and other traditional methods

Source: client exit interview 
All of the new

NORPLANT $^{\circledR}$ users were

asked about the last

family planning method

used before

NORPLANT ${ }^{\circledR}$ insertion

and their reasons for

discontinuing or switching

from that method (Figure

14). About $10 \%$ of

women reported that no

method was used before

NORPLANT $^{\circledR}$ (i.e., new
Figure 15: Factors Affecting the Decision to Accept NORPLANT® Among New Users

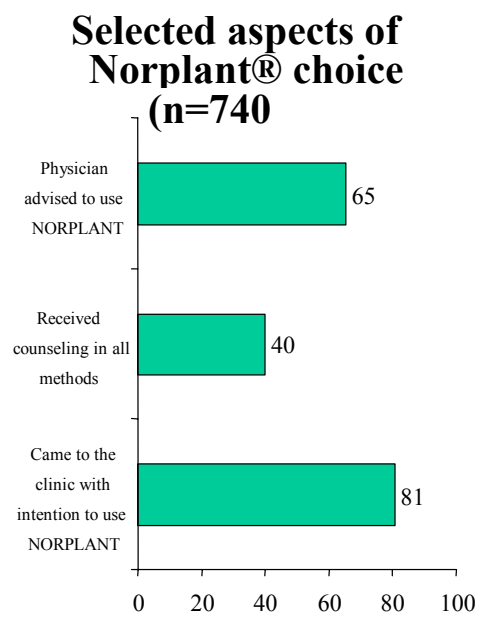

Who finally made Norplant $₫$ choice? $(n=740$

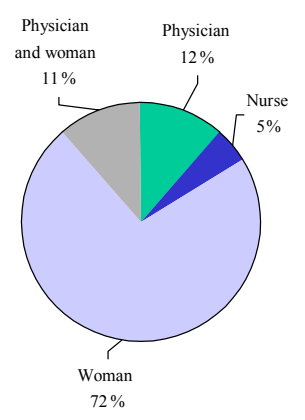

acceptors). The IUD and injectables were used each by about one-third of women before switching to NORPLANT ${ }^{\circledR}$. The pill was used by about one-fourth of women. As expected, method sideeffects were the major reason for discontinuing last method used before NORPLANT ${ }^{\circledR}$ (reported by $70 \%$ of the women). Other reported reasons for discontinuing last method included the need for a more effective method (9\%), method failure $(6 \%)$ and that the woman wants to get pregnant $(4 \%)$ (Figure 14).

Figure 15 provides relevant data on factors affecting the decision to begin using NORPLANT $^{\circledR}$. About four-fifths $(81 \%)$ of the women indicated that they came to the clinic with the intention to use

NORPLANT $^{\circledR}$ (i.e., already decided on the method to be used). About two-thirds $(65 \%)$ of women said that
Figure 16: Information Given to New Clients by Service Providers

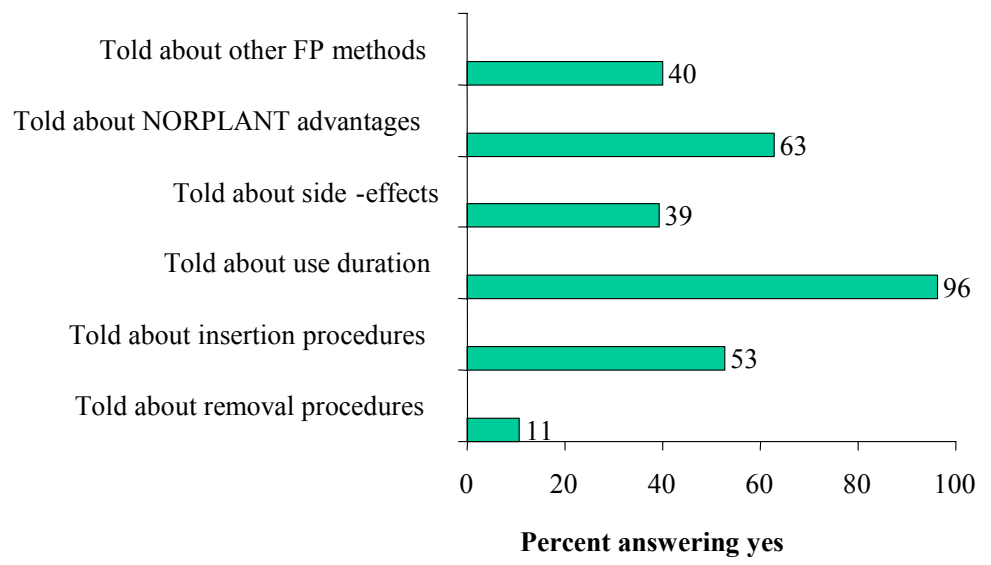

Source: client exit interview $(n=740)$

the physician advised them to use NORPLANT ${ }^{\circledR}$. Only two-fifths $(40 \%)$ of the women interviewed reported that they received counseling on all family planning methods. 
As a following question on who finally made the choice for NORPLANT ${ }^{\circledR}$ method, the majority of the new users $(72 \%)$ stated that they themselves made the final choice and another $11 \%$ reported that the physician and the woman jointly made the decision. These data indicate that women's informed choice was reasonably upheld (Figure 15).

This study also collected information on counseling and information given to clients by service providers before and after NORPLANT ${ }^{\circledR}$ insertion. Figure 16 shows information given to new users by service providers before the NORPLANT ${ }^{\circledR}$ insertion procedure. Almost all of the women (96\%) reported being told about the use duration of NORPLANT ${ }^{\circledR}$ (i.e., five years). About two-thirds were told about NORPLANT ${ }^{\circledR}$ advantages and one-half were told about NORPLANT ${ }^{\circledR}$ insertion procedures. Counseling on potential side-effects was provided to only $39 \%$ of the women. In fact, during client exit interviews, most new users reported that physicians told them "if anything wrong happened, return to the clinic," without specifying the potential side-effects (not shown in the figure). In addition, only $11 \%$ of the new users were told about NORPLANT ${ }^{\circledR}$ removal procedures before having the implants inserted. This last point indicates a short-coming in the provision of preinsertion information.

All new users were asked to report on follow-up information given to them by service providers after NORPLANT ${ }^{\circledR}$ insertion (Figure 17). The majority reported being told about the need for follow-up visits (92\%).

However, only $82 \%$ reported that they received a card including the schedule for follow-up visits. Although the vast majority were told about NORPLANT ${ }^{\circledR}$ use duration $(96 \%$, see Figure 16), only about one-fourth of them were told about the due date for removal before they left the clinic.

\section{Figure 17 : Follow-up Information Given to New Acceptors after NORPLANT® Insertion}

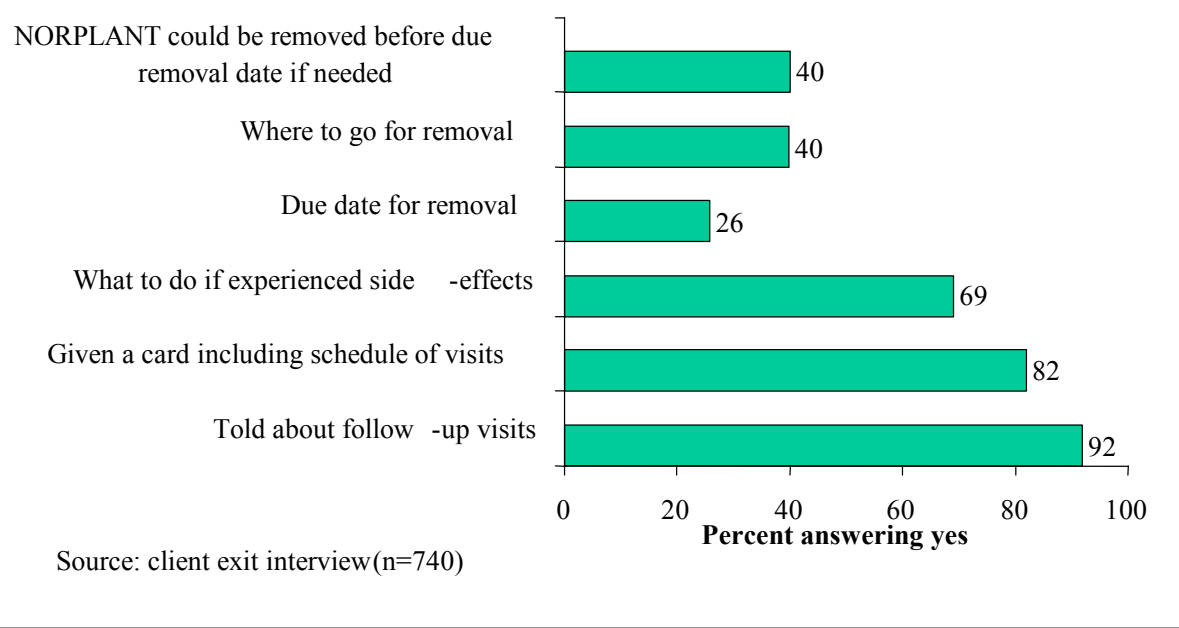

This is a serious information gap that needs to be emphasized in provider training. Also, only about two-fifths of clients were told that NORPLANT ${ }^{\circledR}$ could be removed before the due date for removal if needed, and almost the same proportion of women were told about clinics that provide removal 
services. In addition, about $69 \%$ of women were advised what to do in case they experienced sideeffects (Figure 17).

The study examined the satisfaction with the NORPLANT ${ }^{\circledR}$ method and Figure 18: Satisfaction with NORPLANT® Methods and Services among New Clients

related aspects of service provision received among new users. Almost all new clients $(98 \%)$ reported that the insertion procedure went well and no problems were faced. About 74 percent reported that they didn't feel pain or fear during the insertion procedure (Figure

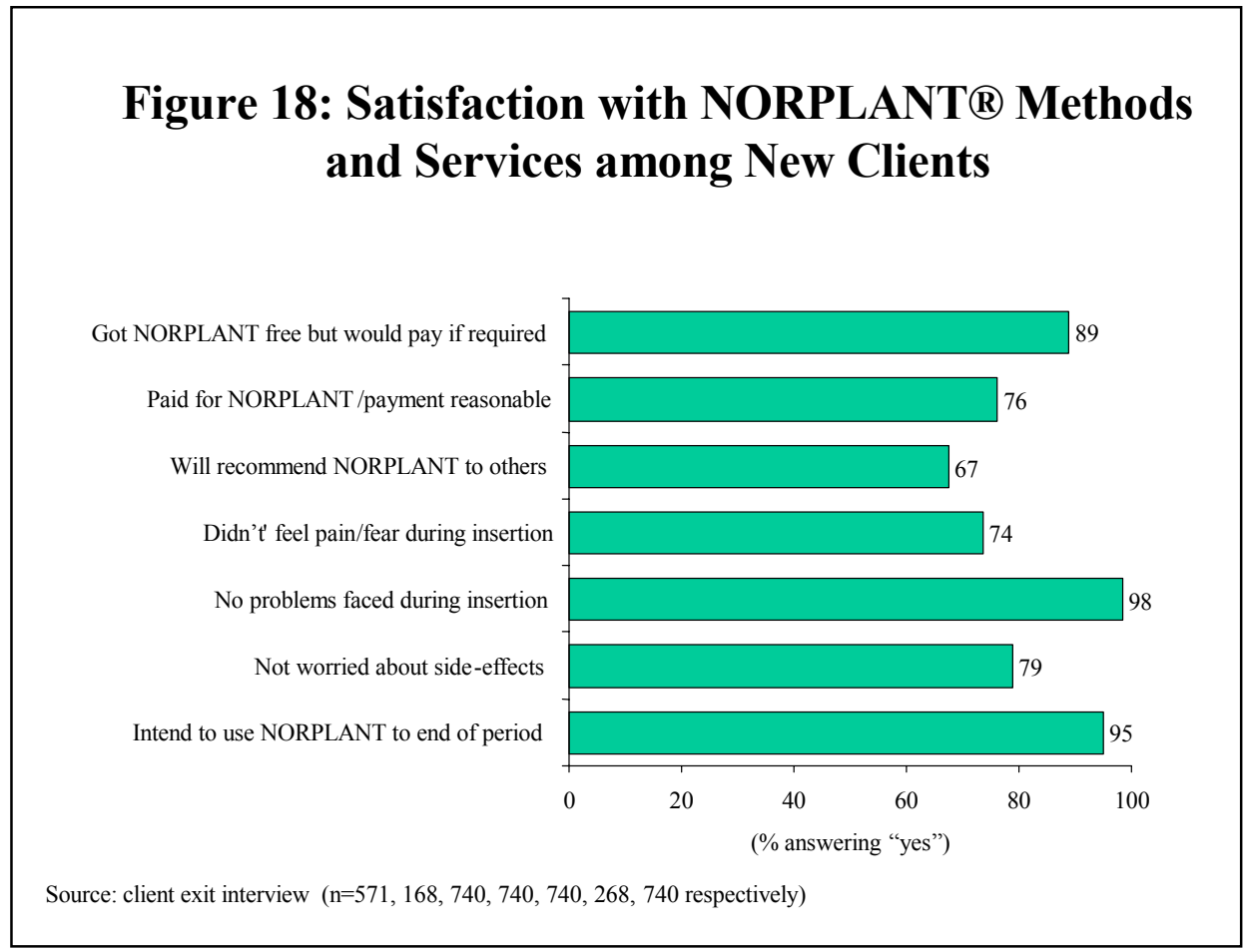

18). Eighty-nine percent of the new users who received a free method reported that they would still request NORPLANT ${ }^{\circledR}$ insertion if they were asked to pay for it. Seventy-six percent of the new users who paid for the method reported that the payment made was reasonable (mean payment for the method was LE 16.9). About two-thirds (67\%) of the new users reported that they would recommend NORPLANT ${ }^{\circledR}$ to others.

\section{NORPLANT ${ }^{\circledR}$ Use}

\section{Dynamics}

The experiences of continuing users of NORPLANT $^{\circledR}$ (i.e., women who had NORPLANT ${ }^{\circledR}$ inserted 1-4 years ago) are reported on in this section.

The most important advantages and

disadvantages of NORPLANT ${ }^{\circledR}$ as reported by continuing users are shown in Figure 19. The two most commonly cited advantages to NORPLANT ${ }^{\circledR}$ use are its long duration $(36 \%)$ and fewer side effects $(24 \%)$. In fact some of the continuing users mentioned that they had tried some other family 
planning methods previously, but were not able to tolerate the side-effects. They felt that they had less side-effects with NORPLANT ${ }^{\circledR}$ or side-effects that were more tolerable (not shown in Figure 19). An additional $12 \%$ of the continuing users reported the principal advantage was not having to worry about remembering to take a pill every day, or an injectable every 3 months. It is interesting to note that about $6 \%$ of the women thought that NORPLANT ${ }^{\circledR}$ has no singular advantage over other contraceptives.

With regard to the principal disadvantage, it is also interesting to note that about two-fifths (42\%) of

\section{Figure 20 : Principal Reason for Discontinuing Use of NORPLANT® before 5 Years}

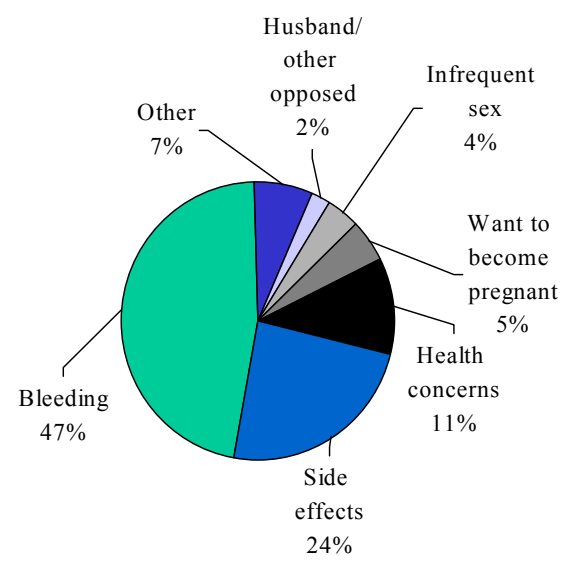

Source: home interviews $\mathrm{n}=103$

the continuing users do not perceive any disadvantage for NORPLANT ${ }^{\circledR}$ (Figure 19). The most frequently reported disadvantage was that NORPLANT ${ }^{\circledR}$ causes menstrual cycle disturbance (cited by $26 \%$ ). Other reported disadvantages included headache, weight gain and pain in body (reported each by about $6 \%$ ).

Women who had NORPLANT ${ }^{\circledR}$ removed before 5 years of use (17 percent) were asked to give the principal reasons for early removal (Figure 20). Experiencing bleeding was the main cause of dissatisfaction with the method that led to early removal (reported by about one-half of women who stopped using NORPLANT ${ }^{\circledR}$ An additional one-fourth mentioned that they removed NORPLANT ${ }^{\circledR}$ because of its other side-effects. Some women $(9 \%)$ removed NORPLANT ${ }^{\circledR}$ due to reasons not related to the method, for example, they wanted to become pregnant $(5 \%)$ or infrequent sex (4\%). Women who had NORPLANT ${ }^{\circledR}$ removed before 5 years were also asked about who had made the decision for removal and where did they go to get NORPLANT ${ }^{\circledR}$ removed. Data in Table 11 show that about two-thirds (62\%) of those women reported that the decision was made by themselves, while an additional $29 \%$ of women stated that the physician recommended removal. Only a few women $(6 \%)$ said that their husbands asked them to have NORPLANT ${ }^{\circledR}$ removed. 
The majority $(58 \%)$ of the removal cases

occurred in the same health facilities where NORPLANT ${ }^{\circledR}$ NORPLANT $^{\circledR}$ had been inserted. It is interesting to note that about onefifth $(21 \%)$ of the women went to a private doctor to have NORPLANT ${ }^{\circledR}$ removed. Another $17 \%$ reported that they went to a different university hospital for NORPLANT ${ }^{\circledR}$ removal (Table 11). Women who did not have NORPLANT $^{\circledR}$ removed at the same health facility were asked about the reason (not shown in Table 11). About one-third of women in this group $(\mathrm{n}=45)$ indicated that the physician who made the insertion couldn't remove the capsules. An additional one-half of the women said that they were referred to another health facility for removal and about $12 \%$ said that the private physician is better (not shown in a table or graph).

The majority of women were able to get NORPLANT ${ }^{\circledR}$ removed through making one visit to the health facility (90\%), (Table 11). Other women (about one-tenth), however, had to make at least two visits to the health facility to get NORPLANT ${ }^{\circledR}$ removed. These findings indicate that providers need more training in removal procedures. Both NORPLANT ${ }^{\circledR}$ continuers and discontinuers were asked about duration of NORPLANT ${ }^{\circledR}$ use since insertion (Figures 21 and 22). Among the continuing users about the one-third reported use for a period of less than one year, and an additional one-third reported
Table 11: Decision Makers and Place of Removal as Reported by Discontinued Users ( $n=103)$

\begin{tabular}{|l|c|}
\hline & Percent \\
\hline Who made the decision to remove & \\
NORPLANT $®$ ? & 62.1 \\
Client & 29.1 \\
Doctor & 5.8 \\
Husband & 1.0 \\
Relatives & 1.9 \\
Friends & \\
& \\
Place of removal & 58.3 \\
Same place of insertion & 21.4 \\
Private doctor & 16.5 \\
Another university hospital & 1.0 \\
Another teaching hospital & 1.9 \\
MOHP hospital & 1.0 \\
Other & \\
& \\
\hline Number of removal sessions & 90.3 \\
1 & 6.8 \\
2 & 2.9 \\
\hline
\end{tabular}

Source: home interviews

\section{Figure 21: Duration of NORPLANT ${ }^{\circledR}$ Use (years)}

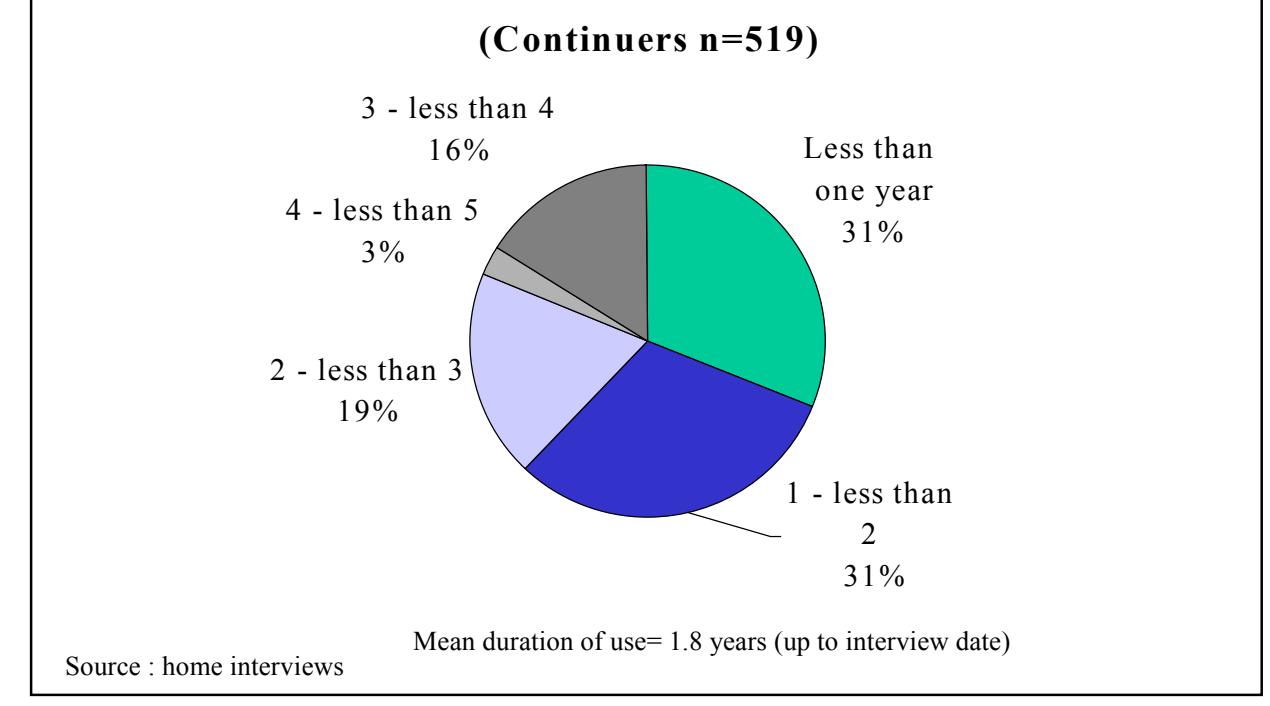


use for 1-2 years (see Figure 21). Close to one-third of women reported a duration of 2-4 years of use. Only 3 percent of women reported a period of 4-less than 5 years. This group is approaching the end of effective use duration and will be due for removal shortly.

\section{Figure 22: Duration of NORPLANT® Use (years)}

Approximately one-third $(30 \%)$ of the women who discontinued use of NORPLANT $^{\circledR}$ could not remember how long they had used the method (Figure 22). An additional one-third reported having the implants removed fairly

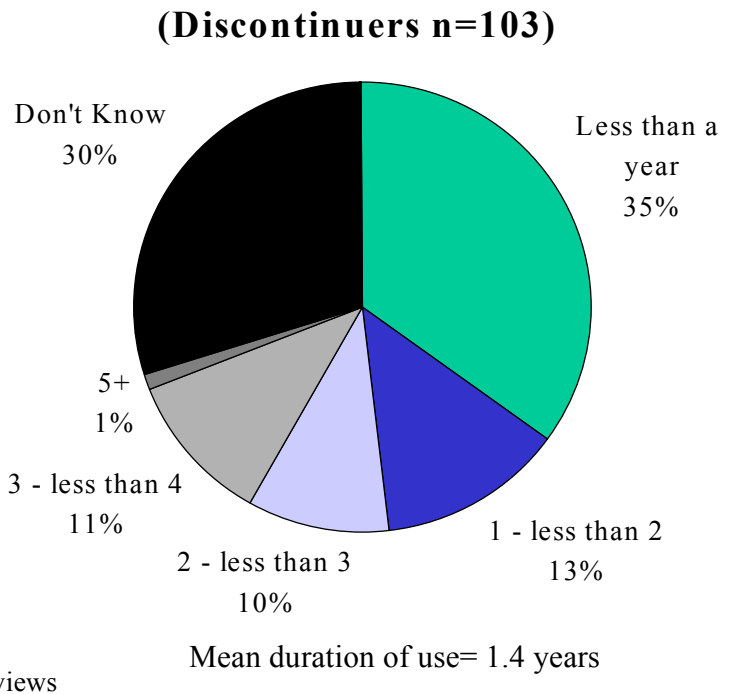

soon after insertion (less than one year use). Between 10-13\% used NORPLANT ${ }^{\circledR}$ for 1-2, 2-3 or 34 years before removal. Women who had NORPLANT ${ }^{\circledR}$ removed in about due time (in fact beyond 5 years) represented only one percent of this group. Overall, the average duration of NORPLANT ${ }^{\circledR}$ use among continuers and discontinuers was 1.8 and 1.4 years, respectively. The short average duration of NORPLANT ${ }^{\circledR}$ use among discontinuers (1.4 years, compared to NORPLANT $^{\circledR}$ use duration of 5 years) would have cost implications that need to be analyzed.

Both continuing users and discontinuers were asked about side-effects experienced during NORPLANT ${ }^{\circledR}$ use. As expected, substantially higher proportions of

\section{Figure 23 : Side Effects Experienced during NORPLANT® Use}

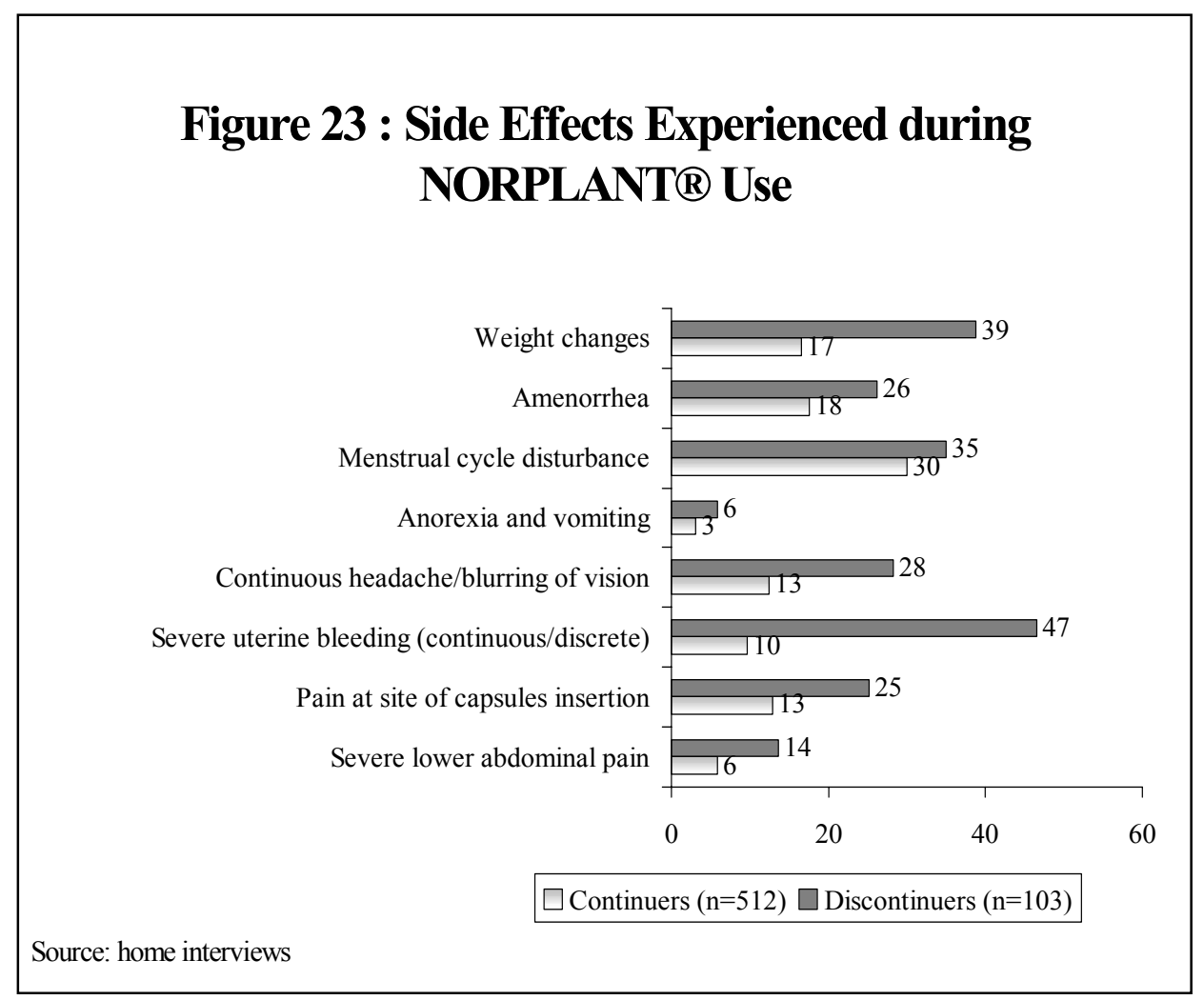

NORPLANT ${ }^{\circledR}$ discontinuers reported experiencing NORPLANT ${ }^{\circledR}$ side-effects compared to the 
continuers group (see Figure 23). Among the discontinuers group the most frequently reported sideeffects experienced were severe bleeding (47\%), weight changes (39\%), menstrual cycle disturbances (35\%) and suffering continuous headache (28\%). For the continuers group, the most frequently reported side-effects for NORPLANT ${ }^{\circledR}$ were menstrual cycle disturbance $(30 \%)$, amenorrhoea (18\%), weight changes (17\%) and pain at site of insertion (13\%) (Figure 23).

These types of reported side-effects conform with findings indicated by other studies (Institute of Medicine, 1998, EFCS, 1995,

National Family Planning

Coordinating Board, Indonesia 1993,

Hassan et al, 1992). Table 12

provides additional data on the experience with NORPLANT ${ }^{\circledR}$ removal. Discontinued users were asked if the rods were removed easily. About one-half of them reported that rods were not easily removed. Among this group, major reasons reported for difficulty in removing the rods were having pain at capsule site (43 percent) and too long a time for removal (37 percent). Another perspective of how NORPLANT $^{\circledR}$ users experience side-effects is given in Table 13. About $58 \%$ of the women who had NORPLANT ${ }^{\circledR}$ inserted 1-4 years ago $(n=624)$ reported health problems that they thought were related to NORPLANT ${ }^{\circledR}$ use. The most frequently mentioned problems were menstrual cycle disturbance (58\%), suffering from continuous

Table 12: Experience with NORPLANT ${ }^{\circledR}$ Removal as Reported by Discontinued Users

\begin{tabular}{|l|l|}
\hline Was the rods' removal easy? $(\mathbf{n = 1 0 3 )}$ & Percent \\
Yes & 48 \\
No & 52 \\
\hline Why was it difficult? $(\mathbf{n}=\mathbf{5 4})$ & \\
Pain at capsule site & 43 \\
Excessive bleeding in arm & 15 \\
Only local anesthesia given & 17 \\
Too long time for removal & 37 \\
Fibrosis around implanted capsules & 20 \\
Other & 10 \\
\hline
\end{tabular}

Source: home interviews

Table 13: Tolerance of Side-effects and Medical Assistance Received

\begin{tabular}{|lr|}
\hline & Percent \\
Have you experienced any body changes / health problems & \\
that you think it happened due to NORPLANT ${ }^{\circledR}$ use? & \\
(n=624) & 58 \\
Yes & 42 \\
No & \\
What were these problems? ( $\mathrm{n}=363$ ) & 58 \\
Menstrual cycle disturbances & 33 \\
Weight change & 12 \\
Abdominal pain & 26 \\
Continuous headache & 28 \\
Other pain & 19 \\
General debility & 31 \\
Other & \\
Have you consulted a physician about these problems? & \\
(n=363) & 54 \\
Yes & 46 \\
No & \\
What was the physician's advice? (n=196) & 28 \\
Reassured me & 14 \\
Recommended NORPLANT ${ }^{\circledR}$ removal & 50 \\
Gave me treatment & 7 \\
Advised that changes are not due to NORPLANT ${ }^{\circ}$ & 2 \\
Other &
\end{tabular}
headache (26\%) and having some body pain (28\%). Only about one-half of women who faced medical problems went to physicians seeking medical advice. Among those women who sought 
care from a physician, $28 \%$ reported that the doctor reassured them that these problems were simple and normal with NORPLANT ${ }^{\circledR}$ use.

However one-half of the women who sought care received treatment, while about $14 \%$ of the women were advised by the physicians to have NORPLANT ${ }^{\circledR}$ removed. Women who had NORPLANT $^{\circledR}$ removed were asked if they had switched to another family planning method after removal. Seventy-one percent answered affirmatively (see Figure 24). Among this group, about $38 \%$ switched to the IUD, about $33 \%$ switched to the pill, and about $26 \%$ began using injectables.

Among all of the sample women who began using NORPLANT ${ }^{\circledR}$ between 14 years ago, the vast majority reported general satisfaction with the method, and the services (Figure 25). The large majority $(97 \%)$ reported that the insertion procedure went well with about $80 \%$ reporting having no felt pain or fear

\section{Figure 24: Switching to another Method among NORPLANT ${ }^{\circledR}$ Discontinuers}
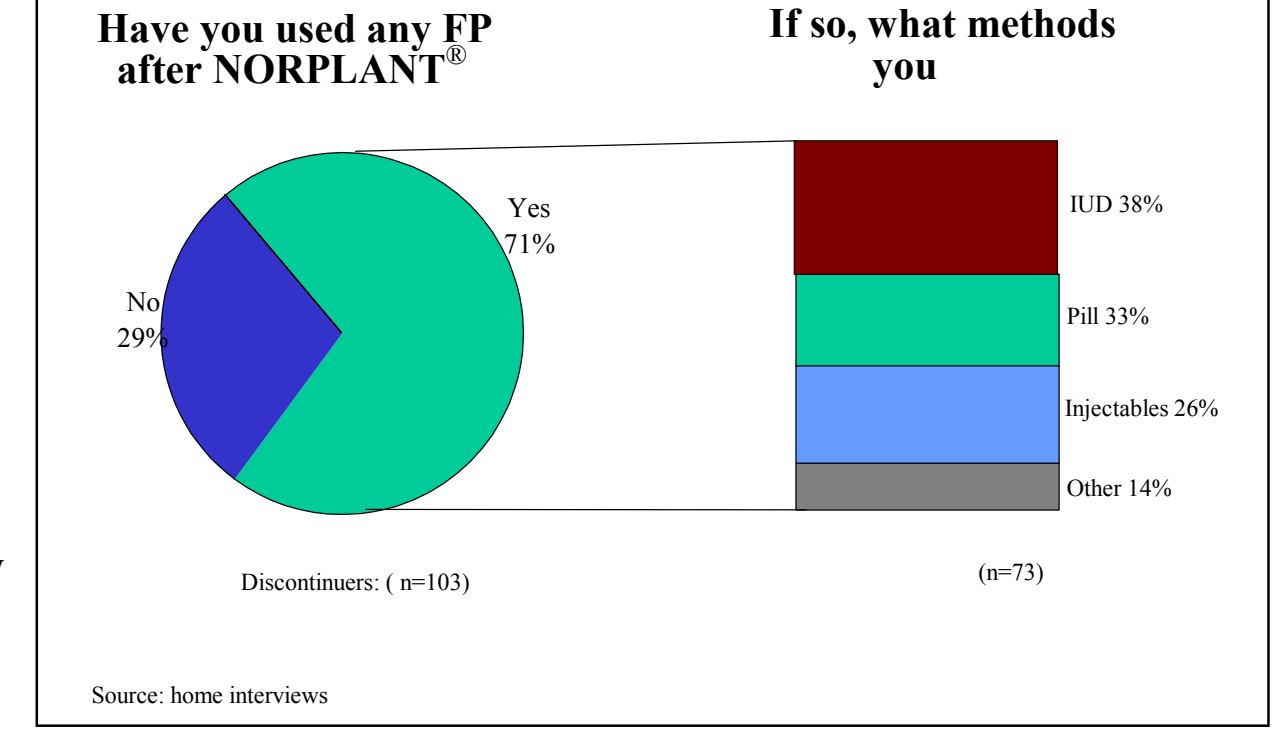

Source: home interviews

\section{If so, what methods you}

during the insertion procedure. Almost all women who reported that the capsules were recognized by others in their arms $(n=139)$ indicated that they were not annoyed because of that. About 90 percent of women who were still using NORPLANT ${ }^{\circledR}$ intend to continue NORPLANT ${ }^{\circledR}$ use to the end of the five-year duration (figure 25). Almost two-thirds (61\%) of all women stated that they would recommend NORPLANT ${ }^{\circledR}$ to others. 


\section{OVERVIEW OF FINDINGS AND PROGRAM IMPLICATIONS}

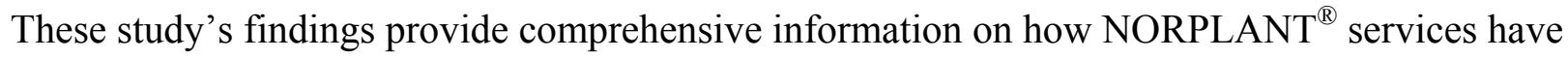
been administered and used through the on-going Introduction Program that is now approaching five years of operation.

\section{Major study findings with program implications are highlighted below:}

1. The record system audit indicated that about one-third of clients available in clinic registers were not entered in the central MOHP MIS. The following are possible reasons:

- Clinics ran out of supplies of client information sheets that are completed at the clinic level for women who had NORPLANT ${ }^{\circledR}$ inserted and sent to the central MIS (monitoring visits during field data collection showed that this could be the case for some clinics).

- Client information sheets may have been completed at clinics and sent to central MIS, but some client information items were missing and the sheets were returned to the clinics for adding the missing information items. Some of these sheets may not have been sent back again to central MIS.

2. Even in situations where client records existed in both the MIS and clinic registers, cases with completely matched client information data (perfect fit) were very few. While data on the date of insertion were highly accurate (mean concordance in this information item at MIS and clinic registers was 0.95 ), data on the due date for removal and information on women's addresses were defective and incomplete (mean concordance was 0.40 and 0.24 , respectively).

3. Based on the above findings, and keeping in mind the fact that only $56 \%$ of women's addresses

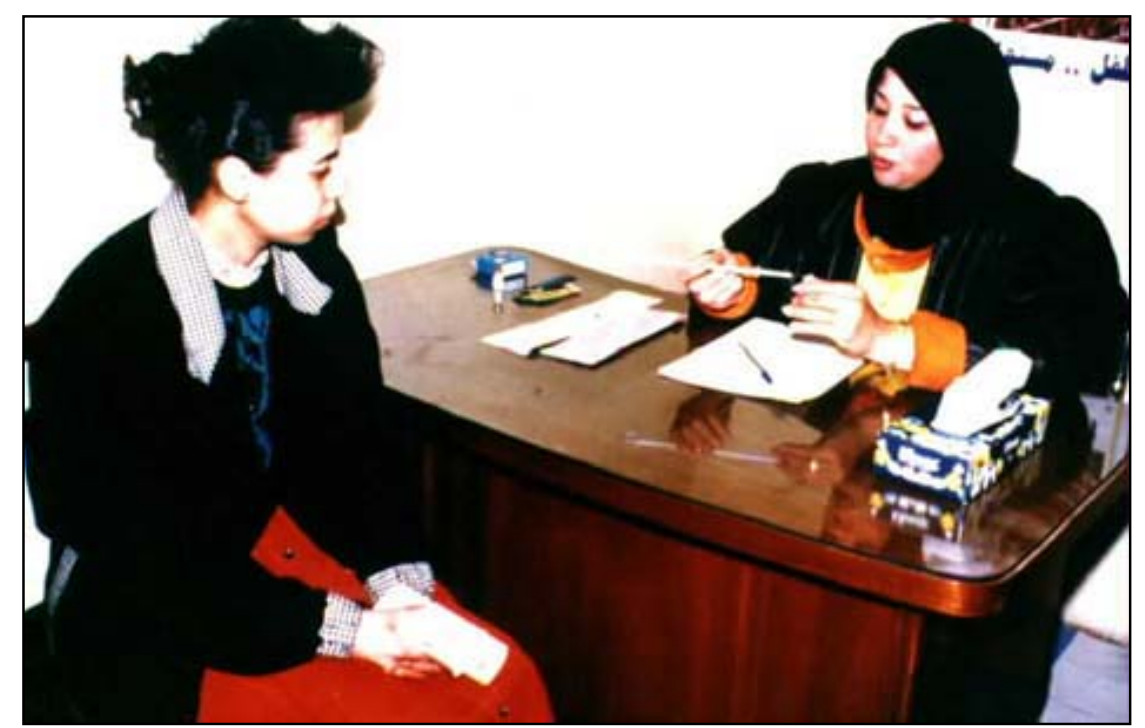
were complete enough for the field worker to locate, it appears that special mechanisms need to be developed in order to strengthen the capability of NORPLANT ${ }^{\circledR}$ MIS to identify and locate women eligible for removal.

4. The study also indicated that, although a client follow-up system is in place to inform women who had NORPLANT ${ }^{\circledR}$ inserted about the schedule of follow-up visits (through giving the 
woman a card), this system is not completely functional. About 15 percent of the women reported that service providers did not give them a card. Moreover, about two-fifths of the women indicated that they received a card but that it was later lost. Furthermore, if women did not return to clinic for follow-up visits there was no system in place at the clinic to follow up women who failed to make the visits to clinics. The implication of the above findings is that some women eligible for removal might not be reached unless women themselves can remember the due date for removal and seek removal service.

5. The study findings indicated that physicians reported that they need more training on NORPLANT ${ }^{\circledR}$ insertion and removal (reported by 23 and 53 percent, respectively). Also, physicians reported facing some difficulties during removal, including breaking of rods, incorrect insertion, and difficulties in identifying the exact site of the implanted capsules. These findings call for the need for structured assessment of both the quality of training received as well as physicians' training needs.

6. Women who had NORPLANT ${ }^{\circledR}$ removed $(n=103)$ did report difficulties with the removal experience. About two-fifths of those women went to a health facility for removal other than the facility where the NORPLANT ${ }^{\circledR}$ was inserted. About one-tenth of the women complained that they had to make at least two visits to the clinic to get NORPLANT ${ }^{\circledR}$ removed. Additionally, one-half of women said that the removal procedure was difficult. Among this latter group, 43\% said that they felt pain at the site of capsules and $47 \%$ reported too long a removal time.

7. The majority of women who had NORPLANT ${ }^{\circledR}$ inserted $1-4$ years ago $(n=624)$ were comfortable with NORPLANT ${ }^{\circledR}(83 \%)$. About $61 \%$ of them reported that they will recommend NORPLANT ${ }^{\circledR}$ to others. The majority of them wanted to terminate childbearing (91\%). According to them, they liked NORPLANT ${ }^{\circledR}$ because it could be used for five years, its use is associated with fewer side-effects, they do not need to remember to do anything to avoid pregnancy, and it is an effective method. Also, many women (two-fifths) did not perceive any disadvantages for NORPLANT ${ }^{\circledR}$. Furthermore, the majority of women who received the method free (about 90\%) said that they would pay for the method if requested. However, among this group, the majority of women who discontinued NORPLANT ${ }^{\circledR}$ use $(n=103)$ were less satisfied with the method. Only 42 percent of this group reported that they were comfortable with NORPLANT $^{\circledR}$ use and 28 percent said that they will recommend NORPLANT ${ }^{\circledR}$ to others.

8. Despite overall satisfaction with the NORPLANT ${ }^{\circledR}$ method, many women reported being worried about side-effects. Experiencing severe bleeding, weight changes, menstrual cycle 
disturbances, headache and pain at insertion site were the most frequently reported-side effects. In general, about one-half of women who had NORPLANT ${ }^{\circledR}$ inserted 1-4 years ago reported facing health problems that they thought were related to NORPLANT ${ }^{\circledR}$ use. Only about one-half sought medical advice. In one-half of these cases $(n=196)$, the physician gave women medication. It is not known to what extent medication given in such situations has been discussed and/or recommended during training/preparing NORPLANT ${ }^{\circledR}$ service provision protocols.

9. Irregular supplies of NORPLANT ${ }^{\circledR}$ capsules seem to occur with implications for free and informed method choice as well as for exposure to unplanned pregnancies. About one-half of physicians said that they face occasional shortages of NORPLANT ${ }^{\circledR}$ supplies. In this situation, physicians reported that they ask the woman who requested NORPLANT ${ }^{\circledR}$ insertion to come later when supplies are made available, or they ask her to use another method. Many physicians $(42 \%)$ said that they give women a temporary method until NORPLANT ${ }^{\circledR}$ supplies become available.

10. The study findings did not suggest the presence of negative attitudes by service providers toward NORPLANT ${ }^{\circledR}$ as a family planning method. Physicians insert NORPLANT ${ }^{\circledR}$ upon request by women when they think that there is no contraindication for NORPLANT ${ }^{\circledR}$. It is noted that the study was only conducted in some NORPLANT ${ }^{\circledR}$ service delivery sites, and the sample of providers is not necessarily representative of all Egyptian physicians and nurses.

11. The study findings indicated that women received partial counseling and information on NORPLANT $^{\circledR}$. Only two-fifths of the new users reported being told about side-effects and about one-half said that they were told about insertion procedures. Also, follow-up information given to women after NORPLANT ${ }^{\circledR}$ insertion was not complete. Only one-fourth of the new users were told about the due date for removal (though almost of them were told that NORPLANT ${ }^{\circledR}$ use duration is five years), and two-fifths were told about where to go for removal.

12. The findings reflected a lack of consensus among physicians regarding NORPLANT ${ }^{\circledR}$ contraindication. There also seems to be a need to train providers about the most appropriate candidates for NORPLANT ${ }^{\circledR}$ use.

13. The study findings indicated that about one-half of women who discontinued NORPLANT ${ }^{\circledR}$ use had the rods removed before the second year of use. This raises the question of whether those 
women were properly counseled about potential NORPLANT ${ }^{\circledR}$ side-effects at the time of the insertion. Also, do health providers adequately inform women about advantages and disadvantages of NORPLANT ${ }^{\circledR}$ and determine candidates for NORPLANT ${ }^{\circledR}$ use?

14. The role of media was called upon in promoting NORPLANT ${ }^{\circledR}$ use. Lack of media advertising about NORPLANT ${ }^{\circledR}$ was reported by both physicians and nurses as the number one problem facing the NORPLANT ${ }^{\circledR}$ Introduction Program.

\section{RECOMMENDATIONS}

\section{Quality of Care}

- $\quad$ Provide additional training to service providers involved in NORPLANT ${ }^{\circledR}$ service provision at both teaching hospitals and MOHP health facilities. The training should target promoting both provider technical knowledge and clinical skills regarding counseling and information given to clients, identifying appropriate candidates for NORPLANT ${ }^{\circledR}$ use, NORPLANT ${ }^{\circledR}$ contraindication, as well as NORPLANT ${ }^{\circledR}$ insertion and removal. Also, provider training programs should include medications prescribed by physicians for side-effects. An assessment of the specific training needs for quality NORPLANT ${ }^{\circledR}$ service provision is needed.

- $\quad$ Promote accessibility to removal services and the quality of these services. As women depend on service providers to both insert and remove the rods, it should be equally easy for women to get NORPLANT ${ }^{\circledR}$ removed and inserted.

- $\quad$ Develop adequate client follow-up systems. At a minimum, due dates for removal should be carefully observed by clinic staff and clients should be contacted and advised for removal.

- $\quad$ Review the need to ensure regular supplies of NORPLANT ${ }^{\circledR}$ and the complex nature of the NORPLANT $^{\circledR}$ service provision system compared with other family planning methods before decisions are made to extend NORPLANT ${ }^{\circledR}$ services to additional health facilities. Keeping these important issues in mind, appropriate decisions might be taken on whether to expand NORPLANT $^{\circledR}$ services horizontally through increased number of service delivery units or vertically through continuous quality improvement and increased demand and client satisfaction. 
- $\quad$ Develop an integrated quality oriented monitoring and evaluation system for NORPLANT ${ }^{\circledR}$ service delivery sites.

\section{Tracking and locating NORPLANT ${ }^{\circledR}$ users}

- $\quad$ Develop appropriate mechanisms to promote central MIS capacity to identify and locate women eligible for NORPLANT ${ }^{\circledR}$ removal. Information items included in clients' records may be minimized to include only basic information needed to track women efficiently to ensure that the rods are removed or replaced when they become no longer effective. The central MIS should be periodically tested for accuracy and completeness of its information. In addition, a decentralized MIS (at the district or clinic level) could be established if the MOHP plans to generate more detailed information regarding the pool of women who seek NORPLANT ${ }^{\circledR}$ insertion.

- Establish clear guidelines requesting clinic staff to give due attention to recording complete information on women's addresses as well as the address of one of their relatives or neighbors according to instructions currently in place. This would greatly promote efforts to locate women eligible for removal.

\section{Program Sustainability}

- $\quad$ Reconsider the decision to provide NORPLANT ${ }^{\circledR}$ free of charge, in view of the findings on women's readiness to pay for NORPLANT ${ }^{\circledR}$ among the majority of women who received a free method. A modest user's fee may be introduced as a first step towards making the NORPLANT ${ }^{\circledR}$ program sustainable.

\section{IEC}

- $\quad$ Develop further IEC components that promote women's knowledge about NORPLANT ${ }^{\circledR}$ as a family planning method. This would help expand contraceptive choice, stress the need to return to clinics to receive follow-up services, and alert women about the need for removal after five years. 


\section{REFERENCES}

Hassan, E., L. Kaffafi, M. El Husseini, K. Hardee-Cleaveland and L. Patter "The Acceptability of NORPLANT $^{\circledR}$ in Egypt”. In Advances in Contraception, Kluwer Academic Publishers, 1992.

Institute of Medicine, 1998 "Contraceptive Research, Introduction, and Use. Lessons from NORPLANT $^{\circledR}$ ". National Academy Press, Washington, D.C., 1998.

National Family Planning Coordinating Board "The 1992 Indonesia NORPLANT ${ }^{\circledR}$ Use-Dynamics Study: Final Report”. Jakarta, Indonesia 1993.

The Egyptian Fertility Care Society "Pre-Introductory Clinical Trail of NORPLANT ${ }^{\circledR}$ Contraceptive Sub-dermal Implants in Egypt". Final Report, 1995. 